\title{
Dry Deposition Velocity Estimation for the Savannah River Site: Part 2 - Parametric and Site-Specific Analysis
}

\author{
BA Napier \\ JP Rishel \\ KM Cook
}

Reviewed by: TR Hay

September 2013

Pacific Northwest

NATIONAL LABORATORY

Proudly Operated by Battelle Since 1965 


\title{
DISCLAIMER
}

This report was prepared as an account of work sponsored by an agency of the United States Government. Neither the United States Government nor any agency thereof, nor Battelle Memorial Institute, nor any of their employees, makes any warranty, express or implied, or assumes any legal liability or responsibility for the accuracy, completeness, or usefulness of any information, apparatus, product, or process disclosed, or represents that its use would not infringe privately owned rights. Reference herein to any specific commercial product, process, or service by trade name, trademark, manufacturer, or otherwise does not necessarily constitute or imply its endorsement, recommendation, or favoring by the United States Government or any agency thereof, or Battelle Memorial Institute. The views and opinions of authors expressed herein do not necessarily state or reflect those of the United States Government or any agency thereof.

\author{
PACIFIC NORTHWEST NATIONAL LABORATORY \\ operated by \\ BATTELLE \\ for the \\ UNITED STATES DEPARTMENT OF ENERGY \\ under Contract DE-AC05-76RL01830
}

Printed in the United States of America

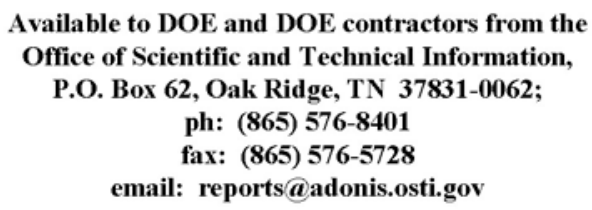

Available to the public from the National Technical Information Service 5301 Shawnee Rd., Alexandria, VA 22312 ph: (800) 553-NTIS (6847) email: orders@ntis.gov $<$ http://www.ntis.gov/about/form.aspx > Online ordering: http://www.ntis.gov 


\section{Dry Deposition Velocity Estimation for the Savannah River Site: Part 2 - Parametric and Site-Specific Analysis}

BA Napier

JP Rishel

KM Cook

September 2013

Prepared for

the U.S. Department of Energy

under Contract DE-AC05-76RL01830

Pacific Northwest National Laboratory

Richland, Washington 99352 



\section{Summary}

Values for the dry deposition velocity of airborne particles were estimated with the GENII Version 2.10.1 computer code for the Savannah River site using assumptions about surface roughness parameters and particle size and density. Use of the GENII code is recommended by the U.S. Department of Energy for this purpose. Meteorological conditions evaluated include atmospheric stability classes D, E, and F and wind speeds of $0.5,1.0,1.5$, and $2.0 \mathrm{~m} / \mathrm{s}$. Local surface roughness values ranging from 0.03 to 2 meters were evaluated. Particles with mass mean diameters of 1, 5, and 10 microns and densities of 1,3 , 4 , and $5 \mathrm{~g} / \mathrm{cm}^{3}$ were evaluated. Site specific meteorology was used to predict deposition velocity for Savannah River conditions for a range of distances from 670 to 11,500 meters. 



\section{Acronyms and Abbreviations}

$\begin{array}{ll}\mu \mathrm{m} & \text { micrometer } \\ \text { AMAD } & \text { Activity Median Aerodynamic Diameter } \\ \mathrm{cm} & \text { centimeter } \\ \mathrm{cm} / \mathrm{s} & \text { centimeter/second } \\ \text { DOE } & \text { U.S. Department of Energy } \\ \text { DV } & \text { deposition velocity (as used in certain referenced DOE documents) } \\ \text { EPA } & \text { U.S. Environmental Protection Agency } \\ \text { GENII2 } & \text { Generalized Environmental Radiation Dosimetry Software System Hanford Dosimetry } \\ & \text { System, Version 2 } \\ \text { ISC3 } & \text { Industrial Source Complex } \\ \text { MACCS2 } & \text { Methods for Estimation of Leakages and Consequences of Releases Accident } \\ \text { M-O } & \text { Consequence Code System, Version 2 } \\ \text { m } & \text { Monin-Obukhov } \\ \text { m/s } & \text { meter } \\ \text { SRS } & \text { meter/second }\end{array}$





\section{Contents}

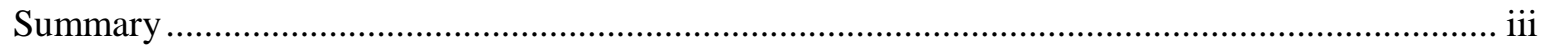

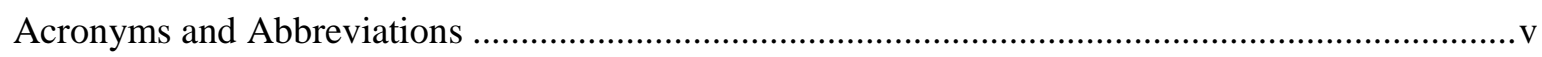

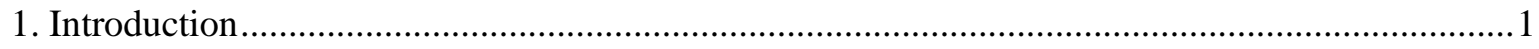

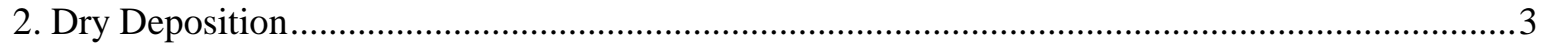

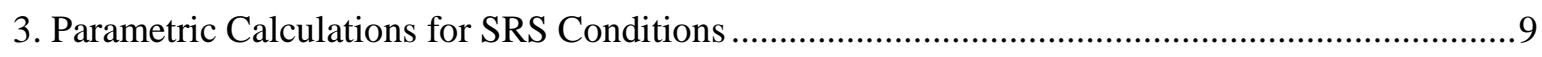

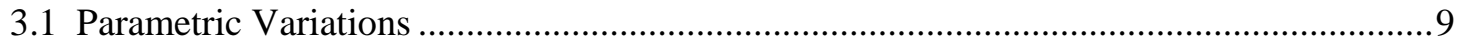

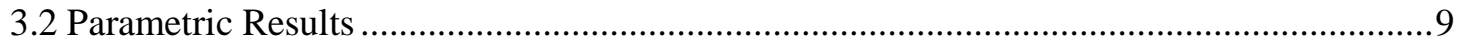

4. $95^{\text {th }}$ Percentile Conditions for Savannah River Site................................................................19

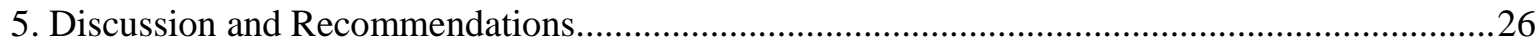

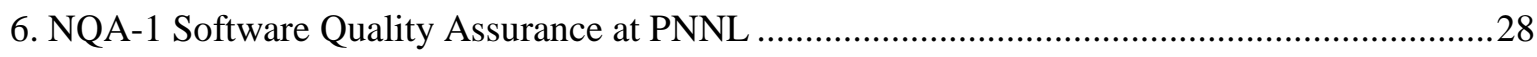

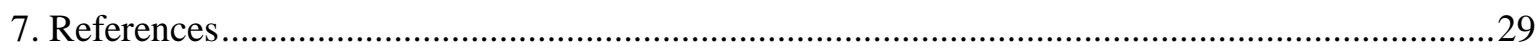




\section{Figures}

Figure 1.Relationship between Stability Class and M-O Length as a Function of Surface Roughness Length (Golder 1972)

Figure 2. Variation of Dry DV as a Function of Wind Speed, Stability Class, and Particle Density; Developed for $1 \mu \mathrm{m}$ Particles and a Surface Roughness of $0.03 \mathrm{~m}$.

Figure 3.Variation of Dry DV as a Function of Wind Speed, Stability Class, and Particle Density;

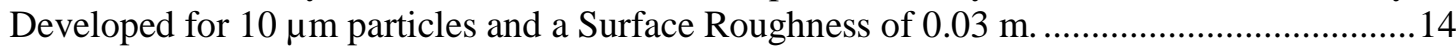

Figure 4.Variation of Dry DV as a Function of Wind Speed, Stability Class, and Particle Density; Developed for $1 \mu \mathrm{m}$ Particles and a Surface Roughness of $1 \mathrm{~m}$..............................................15

Figure 5.Variation of Dry DV as a Function of Wind Speed, Stability Class, and Particle Density; Developed for $10 \mu \mathrm{m}$ particles and a Surface Roughness of $1 \mathrm{~m}$.

Figure 6. Variation of Dry DV as a Function of Surface Roughness; Developed for Particles of Density $1 \mathrm{~g} / \mathrm{cm}^{3}$, Stability Class D.

Figure 7. Variation of Dry DV as a Function of Surface Roughness; Developed for Particles of Density $5 \mathrm{~g} / \mathrm{cm}^{3}$, Stability Class D

Figure 8. Variation of Dry DV as a Function of Surface Roughness; Developed for Particles of Density $1 \mathrm{~g} / \mathrm{cm}^{3}$, Stability Class F.

Figure 9. Variation of Dry DV as a Function of Surface Roughness; Developed for Particles of Density $5 \mathrm{~g} / \mathrm{cm}^{3}$, Stability Class F.

Figure 10. DV as a function of particle mass (volume*density) for various wind speed/stability combinations

Figure 11. Dry deposition velocity (DV, m/s) for 95th percentile Savannah River conditions as a function of downwind distance for multiple combinations of particle size and density. (Figure 11b: same plot including 3 outlier points).

\section{Tables}

Table 1. Settling velocities of particles of various diameter and density, estimated for stability class $\mathrm{D}$ and $3 \mathrm{~cm}$ surface roughness

Table 2. Dry DV (m/s) evaluated as a function of particle diameter, particle density, surface roughness, wind speed, and atmospheric stability class

Table 3. Dry deposition velocity (DV, m/s) for 95th percentile Savannah River conditions as a function of downwind distance, with associated 61-meter wind speed and stability category, for multiple combinations of particle size and density

Table 4. Conversion of 61-meter wind speeds to 10-meter height with use of GENII (Napier et al. 2013) and Hunter and Viner (2013) algorithms 



\section{Introduction}

Concerns were raised by the Defense Nuclear Facilities Safety Board regarding the default values of deposition velocity (DV) used in the Methods for Estimation of Leakages and Consequences of Releases Accident Consequence Code System, Version 2 (MACCS2) computer code. The U.S. Department of Energy (DOE) concluded that the MACCS2 default values of $0.01 \mathrm{~m} / \mathrm{s}$ for unfiltered/unmitigated releases and $0.001 \mathrm{~m} / \mathrm{s}$ for filtered/mitigated releases are not reasonably conservative for all DOE sites and accident scenarios. Until DOE formally revises the MACCS2 Computer Code Application Guidance for Documented Safety Analysis Final Report (DOE 2004) to address this issue, DOE recommends the following if using the MACCS2 computer code to develop conservative results for accident dose consequence calculations:

1. Calculate site-specific DV values for unmitigated/unfiltered and mitigated/filtered particulate releases; or

2. Use default DV values of $0.001 \mathrm{~m} / \mathrm{s}$ for unmitigated/unfiltered particulate releases and $0.0001 \mathrm{~m} / \mathrm{s}$ for mitigated/filtered particulate release; or

3. Use a more sophisticated computer code than MACCS2 to determine the $95^{\text {th }}$ percentile dose at the site boundary.

DOE Safety Bulletin No. 2011-02 (DOE 2011) recommends "While a number of variations in the resistance models are available, the methodology used in the Generalized Environmental Radiation Dosimetry Software System Hanford Dosimetry System, Version 2 (GENII2) code allows for the incorporation of site-specific parameters without an extensive independent modeling effort. In addition, the Office of Health, Safety and Security's recommendation to use a model like GENII2 for unmitigated/unfiltered releases is based on the model's ability to accurately assess the minimum DV found at low wind speeds and smooth surface conditions, while simultaneously being able to predict variations in DV consistent with observed and theoretical patterns that arise from changes in surface roughness and light wind speeds. Given the light winds typically associated with the meteorology that results in the $95^{\text {th }}$ percentile impact, the selected model needs to perform well in these conditions. Further, because the input value for surface roughness significantly affects the results from site to site, a model that can account for variations in surface roughness is also needed. Moreover, the U.S.

Environmental Protection Agency (EPA) approved the use of GENII2 for calculating radiation dose and risk from radionuclides released to the environment. If sites choose to use the GENII2 model, a calculated site-specific value for DV for particulates can then be used as input for the MACCS2 computer code, replacing the default recommended value of $0.1 \mathrm{~cm} / \mathrm{s} . ”$

The GENII Version 2.10.1 computer package (Napier et al. 2012) has been used to estimate dry DV for the Savannah River Site (SRS) as described below. The calculations were prepared in the manner required in the GENII Software Quality Assurance manual (PNNL 2013) and an application package prepared and reviewed. A spreadsheet implementation of the equations described below was used to verify the results, as required by PNNL under Subject Area Safety Software, Exhibit: Utility Calculation Guidance (https://hdi-sa.pnl.gov/standard/6e/6e09e010.htm, effective date March 2007). Discussion of the quality assurance regime under which GENII has been developed and implemented is provided in Section 6. 
This report is a companion and follow-up to a previous report (Napier 2012). In that report, the theory of dry deposition was elaborated and a series of estimates of dry deposition velocity were made for a range of particle sizes, particle densities, wind speeds, surface roughnesses, and meteorological conditions. In this report, that information is extended with additional discussion of dry deposition, the potential effects of distance, and additional particle density and surface roughness conditions. In addition, five years' worth of Savannah River Site meteorological data are used to estimate the conditions applicable at the $95^{\text {th }}$ percentile confidence level for deposition velocity for Savannah River physical and meteorological conditions at a range of distances applicable to facilities at that site.

Following this introductory section, Section 2 provides a theoretical discussion of deposition velocity (reprising and supplementing that in Napier 2012). Section 3 provides an expanded discussion of the parametric investigation of dry deposition velocity as a function of particle size, particle density, wind speed, and meteorological stability. Section 4 applies the GENII methods to Savannah River site-specific meteorology and physical conditions and provides estimates of deposition velocity for conditions that result in the $95^{\text {th }}$ percentile of air concentration per unit release; these are coupled with the type of weather condition that caused them. Section 5 discusses the results of Sections 3 and 4 together and provides recommendations on how to apply the results. Section 6 provides background on the Software Quality Assurance program that is applicable to GENII and the calculations herein. Section 7 provides references for the preceding sections. 


\section{Dry Deposition}

The flux of material to the ground resulting from dry deposition is assumed to be proportional to the material's concentration in the air near the ground. Deposition velocity (DV) is the term given to the constant of proportionality. Thus,

$$
\omega_{i j}(t)=D V_{i j}(t) \chi_{\mathrm{ij}}(1, \mathrm{t})
$$

where $\quad \omega_{\mathrm{ij}}(\mathrm{t})=$ the dry deposition flux at position $\mathrm{i}, \mathrm{j}$ at time $\mathrm{t}$

$\mathrm{DV}_{\mathrm{ij}}(\mathrm{t})=$ the dry deposition velocity at position $\mathrm{i}, \mathrm{j}$ at time $\mathrm{t}$

$\chi_{\mathrm{ij}}(1, \mathrm{t})=$ the concentration at a height of $1 \mathrm{~m}$ at position $\mathrm{i}, \mathrm{j}$ at time $\mathrm{t}$.

It is important to note that the DV is a function of the height at which the concentration is measured or calculated. A reference height of $1 \mathrm{~m}$ is assumed for deposition velocities in the GENII atmospheric models.

Dry deposition velocities have been calculated from experimental data for particles and gases. In general, the deposition velocities observed for any particular material have a wide range of values. The dry DV may be modeled using an analogy to electrical resistance. Resistances are associated with atmospheric conditions, physical and chemical characteristics of the material, and the physical, chemical and biological properties of the surface. Seinfeld (1986) describes the resistance analogy.

For small particles (less than about $10 \mu \mathrm{m}$ ) and gases the resistance model for dry deposition velocities is

$$
D V=\left(\mathrm{r}_{\mathrm{a}}+\mathrm{r}_{\mathrm{s}}+\mathrm{r}_{\mathrm{t}}+\mathrm{r}_{\mathrm{a}} \mathrm{r}_{\mathrm{s}} \mathrm{V}_{\mathrm{s}}\right)^{-1}+\mathrm{v}_{\mathrm{s}}
$$

where

$$
\begin{aligned}
\mathrm{r}_{\mathrm{a}} & =\text { aerodynamic resistance }(\mathrm{s} / \mathrm{m}) \\
\mathrm{r}_{\mathrm{s}} & =\text { surface resistance }(\mathrm{s} / \mathrm{m}) \\
\mathrm{r}_{\mathrm{t}} & =\text { transfer resistance }(\mathrm{s} / \mathrm{m}) \\
\mathrm{v}_{\mathrm{s}} & =\text { the gravitational settling velocity }(\mathrm{m} / \mathrm{s}) ; \text { a function of particle size and density. }
\end{aligned}
$$

The aerodynamic and surface resistances are generally calculated from near surface wind data. In contrast, the transfer resistance is generally a function of the depositing surface.

The aerodynamic resistance is calculated directly from the wind speed and a parameter that is characteristic of the turbulence in the lowest layer of the atmosphere. The usual parameterization for the aerodynamic resistance is

$$
\mathrm{r}_{\mathrm{a}}=\mathrm{U}(\mathrm{z}) / \mathrm{u}^{2}
$$


where $\quad \mathrm{z}=$ the height at which the concentration is estimated (m)

$\mathrm{u}_{*}=$ the characteristic turbulence velocity, called the friction velocity $(\mathrm{m} / \mathrm{s})$

$\mathrm{U}(\mathrm{z})=$ wind speed at height $\mathrm{z}(\mathrm{m} / \mathrm{s})$.

The concentration is approximately constant for $\mathrm{z}<0.2 \sigma_{\mathrm{z}}$ (where $\sigma_{\mathrm{z}}$ is the standard deviation of the concentration in the vertical) as long as the downwind distance is sufficiently large that $\sigma_{\mathrm{z}}$ is greater than or equal to the height of release. Thus, for most elevated release cases, the $10 \mathrm{~m}$ wind speed may be used directly in calculating $\mathrm{r}_{\mathrm{a}}$.

The "friction velocity" is derived from the atmospheric boundary layer similarity theory proposed by Monin and Obukhov (1954). The basic hypothesis of the similarity theory is that a number of parameters in the atmospheric layer near the ground, including the wind profiles, should be universal functions of the friction velocity, a length scale, and the height above ground. The length scale, $\mathrm{L}$, is referred to as the Monin-Obukhov (M-O) length and the ratio $\mathrm{z} / \mathrm{L}$ is related to atmospheric stability. The M-O length is a measure of atmospheric stability. It varies from small negative values (a few meters) in extremely unstable atmospheric conditions to negative infinity as the atmospheric stability approaches neutral from unstable. In extremely stable conditions, the $\mathrm{M}-\mathrm{O}$ length is small and positive. As neutral conditions are approached from stable conditions, the M-O length approaches infinity. Thus, there is a discontinuity in the M-O length at neutral. However, this discontinuity is not a problem because the M-O length is found in the denominator of expressions. When $\mathrm{z} / \mathrm{L}$ is negative and large (e.g., $<-2$ ), the atmosphere is extremely unstable (convective). When $\mathrm{z} / \mathrm{L}$ is near zero, the atmosphere is neutral, and when it is positive and large (e.g., > 1), the atmosphere is extremely stable. A large body of experimental data supports the M-O similarity theory.

The diabatic wind profile is

$$
\mathrm{U}(\mathrm{z})=\frac{\mathrm{u} *}{\mathrm{k}}\left[\ln \left(\frac{\mathrm{z}}{\mathrm{z}_{0}}\right)-\psi\left(\frac{\mathrm{z}}{\mathrm{L}}\right)\right]
$$

where

$$
\begin{aligned}
\mathrm{U}(\mathrm{z}) & =\text { wind speed at height } \mathrm{z}(\mathrm{m} / \mathrm{s}) \\
\mathrm{u}_{*} & =\text { friction velocity (boundary-layer turbulence scaling velocity) }(\mathrm{m} / \mathrm{s}) \\
\mathrm{k} & =\text { von Karman constant, which has a value of about } 0.4 \text { (no units) } \\
\mathrm{z} & =\text { height }(\mathrm{m}) \\
\mathrm{z}_{0} & =\text { measure of local surface roughness (roughness length) }(\mathrm{m}) \\
\Psi & =\text { stability correction factor } \\
\mathrm{L} & =\text { M-O length }(\mathrm{m})
\end{aligned}
$$

The term $\psi(z / L)$ accounts for the effects of stability on the wind profile. In stable atmospheric conditions, $\psi(\mathrm{z} / \mathrm{L})$ has the form $-\alpha \mathrm{z} / \mathrm{L}$, where $\alpha$ is a value between 4.7 and 5.2. For the GENII models, a value of 5 is used for $\alpha$. In neutral conditions $\psi(\mathrm{z} / \mathrm{L})$ is zero, and the diabatic profile simplifies to a logarithmic profile.

In unstable air, $\psi(\mathrm{z} / \mathrm{L})$ is more complicated. According to Panfosky and Dutton (1984), the most common form of $\psi(z / L)$ for unstable conditions is based on the work by Businger et al. (1971) and Paulson (1970). It is 


$$
\psi\left(\frac{\mathrm{z}}{\mathrm{L}}\right)=\ln \left(\left[\frac{1+\mathrm{x}^{2}}{2}\right]\left[\frac{1+\mathrm{x}}{2}\right]^{2}\right)-2 \tan ^{-1} \mathrm{x}+\frac{\pi}{2}
$$

where

$$
\mathrm{x}=(1-16 \mathrm{z} / \mathrm{L})^{1 / 4}
$$

Equation (4) is used to estimate the friction velocity $\left(\mathrm{u}_{*}\right)$ from wind speed, surface roughness, and the M-O length.

Golder (1972) provides a means for converting from stability class estimates to M-O lengths. Figure 1, derived from Golder (1972, Figure 5), shows the range for 1/L as a function of stability classes and surface roughness. Mid-range values for 1/L from this figure are used by the model to estimate 1/L.

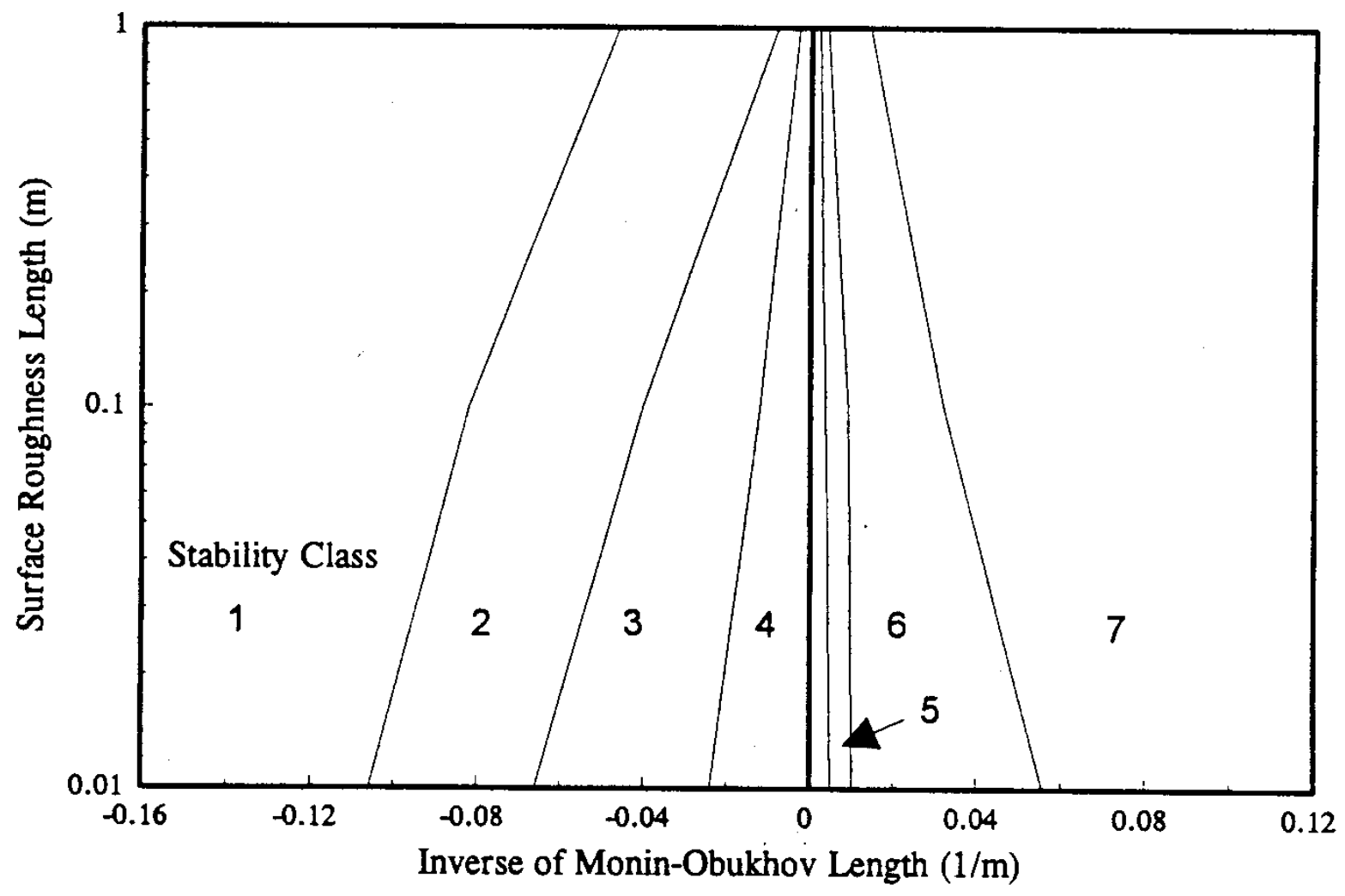

Figure 1. Relationship between Stability Class and M-O Length as a Function of Surface Roughness Length (Golder 1972)

The surface resistance is only a function of the friction velocity. It is

$$
\mathrm{r}_{\mathrm{s}}=2.6 /(0.4 \mathrm{u} *)=6.5 / \mathrm{u} *
$$

where

$$
2.6=\text { a dimensionless empirical constant and } 0.4 \text { is von Karman's constant. }
$$


A gravitational settling term is needed for larger particles where the settling velocity is not negligible. The settling velocity used in the GENII codes is the same as that for the EPA Industrial Source Complex (ISC3) model (EPA 1995) and is given by

$$
\mathrm{V}_{\mathrm{s}}=\frac{\left(\rho-\rho_{\mathrm{AIR}}\right) \mathrm{g} \mathrm{d}_{\mathrm{p}}^{2} \mathrm{C}_{2} \mathrm{~S}_{\mathrm{CF}}}{18 \mu}
$$

where

$$
\begin{aligned}
\rho & =\text { the particle density }\left(\mathrm{g} / \mathrm{cm}^{3}\right) \\
\rho_{\text {AIR }} & =\text { the air density }\left(=1.2 \times 10^{-3} \mathrm{~g} / \mathrm{cm}^{3}\right) \\
\mathrm{d}_{\mathrm{p}} & =\text { the mass mean particle diameter }(\mu \mathrm{m}) \\
\mu & =\text { the absolute viscosity of air }\left(=1.81 \times 10^{-4} \mathrm{~g} / \mathrm{cm} / \mathrm{s}\right) \\
\mathrm{C}_{2} & =\text { air units conversion constant }\left(=1 \times 10^{-8} \mathrm{~cm}^{2} / \mu \mathrm{m}^{2}\right) \\
\mathrm{S}_{\mathrm{CF}} & =\text { the slip correction factor, which is computed as }
\end{aligned}
$$

$$
\mathrm{S}_{\mathrm{CF}}=1+\frac{2 \mathrm{X}_{2}\left(\mathrm{a}_{1}+\mathrm{a}_{2} \exp \left(-\frac{\mathrm{a}_{3} \mathrm{~d}_{\mathrm{p}}}{\mathrm{x}_{2}}\right)\right)}{10^{-4} \mathrm{~d}_{\mathrm{p}}}
$$

where $\mathrm{x}_{2}, \mathrm{a}_{1}, \mathrm{a}_{2}$, and $\mathrm{a}_{3}$ are constants with values of $6.5 \times 10^{-6}, 1.257,0.4$, and $0.55 \times 10^{-4}$, respectively.

The gravitational settling velocity thus estimated is shown in Table 1 for a range of mass mean particle diameters and densities. It can be seen that as particle mass (the product of volume and density) increases, the settling velocity increases and becomes a dominant contributor to the deposition velocity.

Table 1. Settling velocities of particles of various diameter and density, estimated for stability class D and $3 \mathrm{~cm}$ surface roughness

$\begin{array}{ccccc}\begin{array}{c}\text { Mass Mean } \\ \begin{array}{c}\text { Particle } \\ \text { Diameter }(\mu \mathrm{m})\end{array}\end{array} & \begin{array}{c}\text { Density } \\ \left(\mathrm{g} / \mathrm{cm}^{3}\right)\end{array} & \begin{array}{c}\text { Set. Vel. } \\ (\mathrm{m} / \mathrm{s})\end{array} & \begin{array}{c}\text { DV } \\ (\mathrm{m} / \mathrm{s})\end{array} & \begin{array}{c}\text { Set. Vel. as } \\ \text { Fraction of } \\ \text { DV (\%) }\end{array} \\ \begin{array}{ccc}0.000035 \\ 5\end{array} & 1 & 0.0025 & 1 \% \\ 10 & 1 & 0.000776 & 0.0032 & 25 \% \\ 1 & 1 & 0.003057 & 0.0052 & 59 \% \\ 5 & 3 & 0.000105 & 0.0026 & 4 \% \\ 10 & 3 & 0.002331 & 0.0045 & 51 \% \\ 1 & 3 & 0.009177 & 0.0109 & 84 \% \\ 5 & 4 & 0.000140 & 0.0026 & 5 \% \\ 10 & 4 & 0.003108 & 0.0053 & 59 \% \\ 1 & 4 & 0.012237 & 0.0138 & 89 \% \\ 5 & 5 & 0.000175 & 0.0026 & 7 \% \\ 10 & 5 & 0.003886 & 0.0060 & 65 \% \\ & 5 & 0.015298 & 0.0167 & 92 \%\end{array}$


The transfer resistance is used as a mathematical device to establish an upper limit on the deposition velocity. Both $r_{a}$ and $r_{s}$ become small as the wind speed (and therefore the friction velocity) increases. If the transfer resistance is set to zero for neutral conditions when the ratio of $\mathrm{U} / \mathrm{u} *$ is typically about 10 , then the dry DV computed using Equation (2) increases from about $0.006 \mathrm{~m} / \mathrm{s}$ for a wind speed of $1 \mathrm{~m} / \mathrm{s}$ to greater than $0.06 \mathrm{~m} / \mathrm{s}$ when the wind speed is $10 \mathrm{~m} / \mathrm{s}$. Deposition velocities at the upper end of this range are higher than normally assumed for most reactive gases, and the entire range of deposition velocities is above the range of deposition velocities measured for fine particles $(\sim 1 \mu \mathrm{m})$ and nonreactive gases. Assuming transfer resistances of $10 \mathrm{~s} / \mathrm{m}$ for reactive gases and $100 \mathrm{~s} / \mathrm{m}$ for fine particles yields dry deposition velocities that are more consistent with reported values.

As the material is transported downwind, some of it deposits on the ground, reducing the amount in the plume. To account for depletion of the plume from dry deposition, a dimensionless source depletion factor, $D F(x)$, is multiplied against the initial release quantity, $Q_{0}$ :

$$
Q(x)=Q_{0} *[D F(x)]
$$

thereby making the release quantity a function of downwind distance, $Q(x)$. Thus, $D F(x)$ ranges from 0 to 1 and represents the mass fraction that remains in the plume at the downwind distance $x$ (i.e., the mass that has not yet been deposited on the surface). The GENII plume models use a depletion factor that follows from the formulation of Van der Hoven (1968):

$$
F(x)=e^{\left(\int_{0}^{x} \frac{e^{-\frac{1}{2}\left(\frac{H}{\sigma_{Z}(x)}\right)^{2}}}{\sigma_{Z}(x)} d x\right)\left[-\frac{D V}{U} \sqrt{\frac{2}{\pi}}\right]}
$$

where $x$ is downwind distance (m), $\sigma_{z}$ is the vertical diffusion coefficients (m), $H$ is the release height (m), DV is the dry deposition velocity, and $U$ is the wind speed $(\mathrm{m} / \mathrm{s})$. As Horst (1977) notes, Van der Hoven's (1968) source depletion model artificially distributes the effects of dry deposition throughout the entire vertical extent of the plume, resulting in an over-prediction of total deposition with downwind distance. In reality, the reduction in plume concentration from dry deposition occurs in the air in the immediate vicinity of the surface, resulting in less material for deposition at subsequent downwind distances. However, Horst (1977) concludes that Van der Hoven's (1968) assumption is generally fine for near-field (within a few tens of kilometers of the source) depletion.

From the above expression (Eq. 10), it is clear that, for a given atmospheric stability class, plume depletion increases when:

- plume height above ground-level decreases,

- particle dry deposition velocity increases, or

- $\quad$ wind speed decreases.

Interestingly, the depletion factor remains a constant ratio of $\frac{D V}{U}$ for a given stability class and downwind distance. Physically, a faster (slower) deposition velocity is offset by an equally faster (slower) transport wind speed.

The effects of Eq. 10 will be seen in the selection of $95^{\text {th }}$ percentile concentrations. In the Gaussian model, the width of the plume is a function only of the stability class. However, the actual concentration 
in the air is also related to the depleted source term. In many instances, the air concentration is higher with a higher wind speed, because a higher wind speed moves the plume further before it has a chance to deplete - the material is still in the plume rather than being on the ground up wind. Because higher wind speeds are associated with lower atmospheric stability, the $95^{\text {th }}$ percentile dose may not necessarily be associated with the lowest wind speeds.

Separate dry deposition velocities are computed for each type of material in GENII. If the material exists simultaneously in more than one form, then GENII computes a weighted-average dry deposition velocity. The dry DV is the weighted average of dry deposition velocities computed for nonreactive gases, reactive gases, and particles. The averaging weights for each form are based on the fraction of the material in the form. These fractions are input parameters entered by the user. The fractions are constant during a model run. For the analyses here, each particle has only one form. 


\section{Parametric Calculations for SRS Conditions}

Prior to the site-specific calculations, a generic series of parametric calculations were performed at the request of Elliott (2013).

\subsection{Parametric Variations}

Calculations were run for SRS using GENII Version 2.10.1. The particle size distribution released from hypothetical accidents is, of course, unknown. A parametric approach was taken here, as suggested by Elliott (2013). For this set of calculations, a range of particle sizes were evaluated (1, 5, and $10 \mu \mathrm{m}$ mass mean diameters) and, for each, a range of particle densities (1, 3, 4, and $\left.5 \mathrm{~g} / \mathrm{cm}^{3}\right)$. Dry DV does not vary greatly for particles in the range of 0.1 to $1 \mu \mathrm{m}$ activity median aerodynamic diameter AMAD (Sehmel 1984); in this range the mass mean diameter and AMAD are similar.

As discussed above, the DV is a function of several site-specific parameters, which include the local meteorology (wind speeds and stabilities). Three stability classes (D, E, and F) and four wind speeds $(0.5,1,1.5$, and $2.0 \mathrm{~m} / \mathrm{s})$ were used.

GENII input usually includes local temperature and hourly mixing height. The temperature information is used in GENII to estimate plume rise, to adjust wind profiles, and to control wet scavenging of gases. For the parametric task of estimating dry deposition velocities, these functions are not required; therefore, surrogate temperature and ceiling height data from the Savannah River Site were used to fill the data fields but were not used in the calculations.

The representation of surface roughness is a critical first step in many meteorological, wind engineering, and pollutant dispersion modeling activities. It provides an estimate of the drag and turbulent mixing associated with the underlying surface. The roughness length $\left(z_{o}\right)$ is a key parameter in the logarithmic velocity profile based on similarity theory and is commonly used in many models to specify the boundary conditions. The roughness length is directly related to the overall drag of the surface. Mathematically, it represents the distance above the displacement height plane at which the velocity goes to zero. For an initial approximation of the surface roughness, a value of $1 / 10$ of the height of the local roughness elements (trees, buildings, etc.) is often used.

The SRS is in a broad, mostly-forested area. A general rule of thumb is that forested areas have surface roughness values above $20 \mathrm{~cm}(0.2 \mathrm{~m})$. However, the numerical roughness is increased by the topographic relief. Some of the SRS operating areas are in open areas where the local surface roughness may be less, although the "effective" surface roughness may be larger because of the continuing influence of the forests upwind. In order to evaluate the influence of the surface roughness on the deposition velocity, an initial parametric analysis was performed using five surface roughness values. These were 3 , 30, 100, 160, and $200 \mathrm{~cm}(0.03,0.3,1,1.6$, and $2 \mathrm{~m})$, as suggested by Elliott (2013).

\subsection{Parametric Results}

The parameters evaluated include three stability classes (D, E, and F), four wind speeds $(0.5,1,1.5$, and $2.0 \mathrm{~m} / \mathrm{s})$, three particle sizes (1, 5, and $10 \mu \mathrm{m}$ mass mean diameter), four particle densities $(1,3,4$, 
and $5 \mathrm{~g} / \mathrm{cm}^{3}$ ), and five surface roughness lengths (3, 30, 100, 160, and $200 \mathrm{~cm}$ ). This results in a total of 720 individual estimates of dry deposition velocity. These results are presented in Table 2.

Evaluation of the sensitivity of each of these input parameters to the calculated dry DV is presented in the following series of figures. (Note that the scale changes for each figure.)

Figures 2 and 3 illustrate the range of influence of particle size on DV for surface roughness of $3 \mathrm{~cm}$. In Figure 2, dry DV as a function of wind speed is shown for $1 \mu \mathrm{m}$ particles over a range of stability classes and particle densities. For these small particles, there is not much influence on the DV of particle density; wind speed is the dominant influence. In Figure 3, a similar plot is made but with $10 \mu \mathrm{m}$ particles; it is clear that particles of density $3 \mathrm{~g} / \mathrm{cm}^{3}$ deposit about twice as rapidly as particles of density 1 $\mathrm{g} / \mathrm{cm}^{3}$, and that particles of density $5 \mathrm{~g} / \mathrm{cm}^{3}$ deposit about four times faster than particles of density 1 $\mathrm{g} / \mathrm{cm}^{3}$. For these large massive particles, there is a low influence of stability/wind speed but high influence of gravitational settling.

Figures 4 and 5 are parallel to Figures 2 and 3, but for surface roughness of $100 \mathrm{~cm}$. In Figure 4, dry $\mathrm{DV}$ as a function of wind speed is shown for $1 \mu \mathrm{m}$ particles over a range of stability classes and particle densities. For these small particles, there is not much influence on the DV of particle density or stability class; the major influence is wind speed. In Figure 5, a similar plot is made but with $10 \mu \mathrm{m}$ particles; this figure is more emphatic than Figure 3 that particle density is more important than either wind speed or stability class. Also in comparing Figures 2 and 3 with 4 and 5, we can see that a surface roughness change from $3 \mathrm{~cm}$ (a flat field) to $100 \mathrm{~cm}$ (a forested area) has only about a factor of two impact on the deposition velocity.

Figures 6 and 7 present DV as functions of surface roughness, for particles with densities of 1 and 5 $\mathrm{g} / \mathrm{cm}^{3}$ respectively. In Figure 6, we can see that DV increases slightly with wind speed and particle size, as already seen in Figures 2 and 4; surface roughness from 3 to $200 \mathrm{~cm}$ has only about a factor of two influence on the deposition velocity. Figure 7 is similar. For dense particles, DV increases slightly with wind speed and by about a factor of two over the range of particle sizes. Again, surface roughness has only about a factor of two influence over the range 3 to $200 \mathrm{~cm}$, slightly less for the larger particles. Figures 8 and 9 are parallel to Figures 6 and 7 but for Class F. There is little difference between these sets of figures; the DV is slightly lower with Class F than Class D, more obviously with the smaller particles. The general conclusions, that DV increases slightly with wind speed and particle size and surface roughness has about a factor of two influence over the range 0.03 to $2 \mathrm{~m}$, are the same.

These findings are repeated in Figure 10. Figure 10 provides DV as a function of particle mass (volume multiplied by density) for various wind speed/stability combinations. In this figure, particle diameter and density are combined into one term, mass. Over the several order-of-magnitude range illustrated using particles ranging from $1 \mathrm{~g} / \mathrm{cm}^{3}$ density and $1 \mu \mathrm{m}$ diameter to $5 \mathrm{~g} / \mathrm{cm}^{3}$ density and $10 \mu \mathrm{m}$ diameter, DV varies by about a factor of five. Stability and wind speed together account for about a factor of five as well; the overall change in DV shown is about a factor of 25. Surface roughness within each stability/wind speed combination accounts for only about a factor of two. 
Table 2. Dry DV (m/s) evaluated as a function of particle diameter, particle density, surface roughness, wind speed, and atmospheric stability class.

$1 \mu \mathrm{m}$ particle diameter

\begin{tabular}{|c|c|c|c|c|c|c|c|c|c|c|c|c|c|}
\hline \multirow{2}{*}{$\begin{array}{c}Z_{0} \\
(\mathrm{~cm})\end{array}$} & \multirow{2}{*}{$\begin{array}{l}\text { Wind } \\
\text { Speed } \\
(\mathrm{m} / \mathrm{s})\end{array}$} & \multicolumn{3}{|c|}{$\begin{array}{c}\text { density }=1 \mathrm{~g} / \mathrm{cm}^{3} \\
\text { Stability Class }\end{array}$} & \multicolumn{3}{|c|}{$\begin{array}{c}\text { density }=3 \mathrm{~g} / \mathrm{cm}^{3} \\
\text { Stability Class }\end{array}$} & \multicolumn{3}{|c|}{$\begin{array}{c}\text { density }=4 \mathrm{~g} / \mathrm{cm}^{3} \\
\text { Stability Class }\end{array}$} & \multicolumn{3}{|c|}{$\begin{array}{c}\text { density }=5 \mathrm{~g} / \mathrm{cm}^{3} \\
\text { Stability Class }\end{array}$} \\
\hline & & $\mathrm{D}$ & $\mathrm{E}$ & $\mathrm{F}$ & D & $\mathrm{E}$ & $\mathrm{F}$ & D & $E$ & $\mathrm{~F}$ & D & $\mathrm{E}$ & $\mathrm{F}$ \\
\hline 3 & 0.5 & $9.14 \mathrm{E}-04$ & 8.33E-04 & $6.50 \mathrm{E}-04$ & $9.75 \mathrm{E}-04$ & 8.94E-04 & $7.13 E-04$ & $1.01 \mathrm{E}-03$ & $9.25 \mathrm{E}-04$ & 7.44E-04 & $1.04 \mathrm{E}-03$ & $9.56 \mathrm{E}-04$ & $7.75 E-04$ \\
\hline 3 & 1 & $2.50 \mathrm{E}-03$ & $2.32 \mathrm{E}-03$ & $1.89 \mathrm{E}-03$ & $2.56 \mathrm{E}-03$ & $2.38 \mathrm{E}-03$ & $1.95 \mathrm{E}-03$ & $2.59 \mathrm{E}-03$ & $2.41 \mathrm{E}-03$ & $1.98 \mathrm{E}-03$ & $2.62 \mathrm{E}-03$ & $2.44 \mathrm{E}-03$ & $2.02 \mathrm{E}-03$ \\
\hline 3 & 1.5 & $3.33 \mathrm{E}-03$ & $3.11 \mathrm{E}-03$ & $2.59 \mathrm{E}-03$ & $3.39 \mathrm{E}-03$ & $3.18 \mathrm{E}-03$ & $2.65 \mathrm{E}-03$ & $3.42 \mathrm{E}-03$ & $3.21 \mathrm{E}-03$ & $2.68 \mathrm{E}-03$ & $3.45 \mathrm{E}-03$ & $3.24 \mathrm{E}-03$ & $2.71 \mathrm{E}-03$ \\
\hline 3 & 2 & 3.99E-03 & $3.76 \mathrm{E}-03$ & 3.17E-03 & $4.05 \mathrm{E}-03$ & $3.82 \mathrm{E}-03$ & $3.24 \mathrm{E}-03$ & 4.09E-03 & $3.85 \mathrm{E}-03$ & $3.27 \mathrm{E}-03$ & 4.12E-03 & $3.89 \mathrm{E}-03$ & $3.30 \mathrm{E}-03$ \\
\hline 30 & 0.5 & $1.95 \mathrm{E}-03$ & $1.78 \mathrm{E}-03$ & $1.48 \mathrm{E}-03$ & $2.01 \mathrm{E}-03$ & $1.84 \mathrm{E}-03$ & $1.54 \mathrm{E}-03$ & $2.04 \mathrm{E}-03$ & $1.87 \mathrm{E}-03$ & $1.57 \mathrm{E}-03$ & 2.07E-03 & 1.90E-03 & $1.60 \mathrm{E}-03$ \\
\hline 30 & 1 & $4.31 \mathrm{E}-03$ & $4.06 \mathrm{E}-03$ & $3.57 \mathrm{E}-03$ & 4.37E-03 & 4.12E-03 & $3.64 \mathrm{E}-03$ & 4.41E-03 & $4.16 \mathrm{E}-03$ & $3.67 \mathrm{E}-03$ & 4.44E-03 & 4.19E-03 & $3.70 \mathrm{E}-03$ \\
\hline 30 & 1.5 & $5.32 \mathrm{E}-03$ & $5.06 \mathrm{E}-03$ & 4.54E-03 & $5.38 \mathrm{E}-03$ & $5.13 \mathrm{E}-03$ & 4.61E-03 & $5.42 \mathrm{E}-03$ & $5.16 \mathrm{E}-03$ & 4.64E-03 & $5.45 \mathrm{E}-03$ & 5.19E-03 & 4.67E-03 \\
\hline 30 & 2 & $6.02 \mathrm{E}-03$ & $5.78 \mathrm{E}-03$ & $5.26 \mathrm{E}-03$ & $6.09 \mathrm{E}$ & $5.84 \mathrm{E}-03$ & $5.33 \mathrm{E}-03$ & $6.13 \mathrm{E}-03$ & $5.88 \mathrm{E}-03$ & $5.36 \mathrm{E}-03$ & 6.16E-03 & $1 E-03$ & $5.40 \mathrm{E}-03$ \\
\hline 100 & 0.5 & $3.28 \mathrm{E}-03$ & $3.06 \mathrm{E}-03$ & $2.67 \mathrm{E}-03$ & $3.35 \mathrm{E}-03$ & $3.12 \mathrm{E}-03$ & $2.73 \mathrm{E}-03$ & $3.38 \mathrm{E}-03$ & $3.15 \mathrm{E}-03$ & $2.76 \mathrm{E}-03$ & $3.41 \mathrm{E}-03$ & 3.19E-03 & $2.79 \mathrm{E}-03$ \\
\hline 100 & 1 & $5.90 \mathrm{E}-03$ & $5.67 \mathrm{E}-03$ & $5.24 \mathrm{E}-03$ & $5.96 \mathrm{E}-03$ & $5.74 \mathrm{E}-03$ & $5.31 \mathrm{E}-03$ & $6.00 \mathrm{E}-03$ & 5.77E-03 & $5.34 \mathrm{E}-03$ & 6.03E-03 & $5.80 \mathrm{E}-03$ & 5.37E-03 \\
\hline 100 & 1.5 & $6.84 \mathrm{E}-03$ & $6.63 \mathrm{E}-03$ & $6.23 \mathrm{E}-03$ & $6.90 \mathrm{E}-03$ & $6.70 \mathrm{E}-03$ & $6.30 \mathrm{E}-03$ & $6.94 \mathrm{E}-03$ & $6.73 \mathrm{E}-03$ & $6.33 \mathrm{E}-03$ & 6.97E-03 & $.76 \mathrm{E}-03$ & $6.36 \mathrm{E}-03$ \\
\hline 100 & 2 & 7.43E-03 & $7.24 \mathrm{E}-03$ & $6.88 \mathrm{E}-03$ & $7.50 \mathrm{E}-03$ & 7.31E-03 & $6.95 \mathrm{E}-03$ & $7.53 \mathrm{E}-03$ & $7.35 \mathrm{E}-03$ & $6.98 \mathrm{E}-03$ & 7.56E-03 & $7.38 \mathrm{E}-03$ & $7.02 \mathrm{E}-03$ \\
\hline 160 & 0.5 & $4.14 \mathrm{E}-03$ & $3.84 \mathrm{E}-03$ & $3.32 \mathrm{E}-03$ & $4.20 \mathrm{E}-03$ & $3.90 \mathrm{E}-03$ & $3.38 \mathrm{E}-03$ & $4.23 \mathrm{E}-03$ & $3.93 \mathrm{E}-03$ & $3.41 \mathrm{E}-03$ & 4.27E-03 & 3.97E-03 & $3.44 \mathrm{E}-03$ \\
\hline 160 & 1 & 6.67E-03 & $6.41 \mathrm{E}-03$ & 5.93E-03 & $6.73 \mathrm{E}-03$ & $6.48 \mathrm{E}-03$ & 5.99E-03 & 6.77E-03 & $6.51 \mathrm{E}-03$ & $6.03 \mathrm{E}-03$ & $6.80 \mathrm{E}-03$ & $6.55 \mathrm{E}-03$ & $6.06 \mathrm{E}-03$ \\
\hline 160 & 1.5 & $7.51 \mathrm{E}-03$ & $7.29 \mathrm{E}-03$ & $6.86 \mathrm{E}-03$ & 7.57E-03 & 7.36E-03 & $6.93 \mathrm{E}-03$ & 7.61E-03 & $7.39 \mathrm{E}-03$ & $6.97 \mathrm{E}-03$ & 7.64E-03 & 7.43E-03 & 7.00E-03 \\
\hline 160 & 2 & $8.01 \mathrm{E}-03$ & $7.82 \mathrm{E}-03$ & $7.45 \mathrm{E}-03$ & $8.08 \mathrm{E}-03$ & 7.89E-03 & 7.52E-03 & $8.11 \mathrm{E}-03$ & $7.93 \mathrm{E}-03$ & 7.55E-03 & 8.15E-03 & 7.96E-03 & $7.59 \mathrm{E}-03$ \\
\hline 200 & 0.5 & $4.64 \mathrm{E}-03$ & $4.30 \mathrm{E}-03$ & $3.70 \mathrm{E}-03$ & $4.70 \mathrm{E}-03$ & $4.36 \mathrm{E}-03$ & $3.76 \mathrm{E}-01$ & $4.74 \mathrm{E}-03$ & $4.39 \mathrm{E}-03$ & $3.79 \mathrm{E}-03$ & 4.77E-03 & $4.42 \mathrm{E}-03$ & $3.82 \mathrm{E}-03$ \\
\hline 200 & 1 & $7.06 \mathrm{E}-03$ & $6.79 \mathrm{E}-03$ & $6.28 \mathrm{E}-03$ & $7.13 \mathrm{E}-03$ & $6.86 \mathrm{E}-03$ & $6.35 \mathrm{E}-01$ & 7.16E-03 & $6.90 \mathrm{E}-03$ & $6.39 \mathrm{E}-03$ & 7.20E-03 & $6.93 \mathrm{E}-03$ & $6.42 \mathrm{E}-03$ \\
\hline 200 & 1.5 & $7.83 \mathrm{E}-03$ & $7.61 \mathrm{E}-03$ & $7.18 \mathrm{E}-03$ & $7.90 \mathrm{E}-03$ & $7.68 \mathrm{E}-03$ & $7.25 \mathrm{E}-01$ & 7.94E-03 & $7.72 \mathrm{E}-03$ & $7.28 \mathrm{E}-03$ & 7.97E-03 & 7.75E-03 & $7.32 \mathrm{E}-03$ \\
\hline 200 & 2 & $8.29 \mathrm{E}-03$ & $8.10 \mathrm{E}-03$ & $7.73 \mathrm{E}-03$ & $8.36 \mathrm{E}-03$ & 8.17E-03 & $7.80 \mathrm{E}-01$ & 8.39E-03 & $8.21 \mathrm{E}-03$ & 7.83E-03 & $8.43 \mathrm{E}-03$ & $8.24 \mathrm{E}-03$ & 7.87E-03 \\
\hline
\end{tabular}


Table 2 continued: Dry DV (m/s) evaluated as a function of particle diameter, particle density, surface roughness, wind speed, and atmospheric stability class.

$5 \mu \mathrm{m}$ particle diameter

\begin{tabular}{|c|c|c|c|c|c|c|c|c|c|c|c|c|c|}
\hline \multirow{2}{*}{$\begin{array}{c}Z_{0} \\
(\mathrm{~cm})\end{array}$} & \multirow{2}{*}{$\begin{array}{l}\text { Wind } \\
\text { Speed } \\
(\mathrm{m} / \mathrm{s})\end{array}$} & \multicolumn{3}{|c|}{$\begin{array}{c}\text { density }=1 \mathrm{~g} / \mathrm{cm}^{3} \\
\text { Stability Class }\end{array}$} & \multicolumn{3}{|c|}{$\begin{array}{c}\text { density }=3 \mathrm{~g} / \mathrm{cm}^{3} \\
\text { Stability Class }\end{array}$} & \multicolumn{3}{|c|}{$\begin{array}{c}\text { density }=4 \mathrm{~g} / \mathrm{cm}^{3} \\
\text { Stability Class }\end{array}$} & \multicolumn{3}{|c|}{$\begin{array}{c}\text { density }=5 \mathrm{~g} / \mathrm{cm}^{3} \\
\text { Stability Class }\end{array}$} \\
\hline & & $\mathrm{D}$ & $E$ & $\mathrm{~F}$ & $\mathrm{D}$ & $\mathrm{E}$ & $\mathrm{F}$ & D & $\mathrm{E}$ & $\mathrm{F}$ & $\mathrm{D}$ & $E$ & $\mathrm{~F}$ \\
\hline 3 & 0.5 & $1.57 \mathrm{E}-03$ & $1.49 \mathrm{E}-03$ & $1.32 \mathrm{E}-03$ & $3.00 \mathrm{E}-03$ & $2.92 \mathrm{E}-03$ & $2.76 \mathrm{E}-03$ & $3.72 \mathrm{E}-03$ & $3.65 \mathrm{E}-03$ & $3.50 \mathrm{E}-03$ & $4.46 \mathrm{E}-03$ & $4.39 \mathrm{E}-03$ & $4.25 \mathrm{E}-03$ \\
\hline 3 & 1 & $3.15 \mathrm{E}-03$ & 2.97E-03 & $2.54 \mathrm{E}-03$ & $4.54 \mathrm{E}-03$ & $4.36 \mathrm{E}-03$ & 3.93E-03 & $5.25 \mathrm{E}-03$ & 5.07E-03 & 4.64E-03 & 5.96E-03 & $5.78 \mathrm{E}-03$ & $5.35 \mathrm{E}-03$ \\
\hline 3 & 1.5 & $4.00 \mathrm{E}-03$ & $3.78 \mathrm{E}-03$ & $3.25 \mathrm{E}-03$ & $5.42 \mathrm{E}-03$ & $5.20 \mathrm{E}-03$ & 4.66E-03 & 6.13E-03 & $5.91 \mathrm{E}-03$ & 5.37E-03 & $6.85 \mathrm{E}-03$ & $6.62 \mathrm{E}-03$ & $6.08 \mathrm{E}-03$ \\
\hline 3 & 2 & 4.67E-03 & $4.44 \mathrm{E}-03$ & $3.85 \mathrm{E}-03$ & $6.12 \mathrm{E}-03$ & $5.88 \mathrm{E}-03$ & 5.27E-03 & $6.84 \mathrm{E}-03$ & $6.60 \mathrm{E}-03$ & 5.99E-03 & 7.56E-03 & 7.32E-03 & $6.71 \mathrm{E}-03$ \\
\hline 30 & 0.5 & $2.60 \mathrm{E}-03$ & $2.43 \mathrm{E}-03$ & $2.13 \mathrm{E}-03$ & $3.99 \mathrm{E}-03$ & $3.82 \mathrm{E}-03$ & $3.53 \mathrm{E}-03$ & $4.70 \mathrm{E}-03$ & $4.53 \mathrm{E}-03$ & $4.24 \mathrm{E}-03$ & $5.41 \mathrm{E}-03$ & $5.24 \mathrm{E}-03$ & $4.96 \mathrm{E}-03$ \\
\hline 30 & 1 & $4.99 \mathrm{E}-03$ & $4.74 \mathrm{E}-03$ & 4.24E-03 & $6.43 E-03$ & 6.17E-03 & $5.66 \mathrm{E}-03$ & 7.15E-03 & $6.88 \mathrm{E}-03$ & $6.37 \mathrm{E}-03$ & 7.87E-03 & 7.60E-03 & $7.08 \mathrm{E}-03$ \\
\hline 30 & 1.5 & $6.02 \mathrm{E}-03$ & $5.76 \mathrm{E}-03$ & $5.23 \mathrm{E}-03$ & 7.49E-03 & $7.22 \mathrm{E}-03$ & $6.68 \mathrm{E}-03$ & $8.23 \mathrm{E}-03$ & $7.96 \mathrm{E}-03$ & 7.41E-03 & 8.97E-03 & 8.69E-03 & $8.14 \mathrm{E}-03$ \\
\hline 30 & 2 & $6.74 \mathrm{E}-03$ & $6.48 \mathrm{E}-03$ & 5.96E-03 & 8.23E-03 & 7.97E-03 & 7.44E-03 & $8.98 \mathrm{E}-03$ & $8.72 \mathrm{E}-03$ & 8.18E-03 & $9.73 \mathrm{E}-03$ & $9.46 \mathrm{E}-03$ & $8.92 \mathrm{E}-03$ \\
\hline 100 & 0.5 & $3.95 \mathrm{E}-03$ & $3.72 \mathrm{E}-03$ & $3.33 \mathrm{E}-03$ & $5.36 \mathrm{E}-03$ & $5.12 \mathrm{E}-03$ & $4.72 \mathrm{E}-03$ & $6.07 \mathrm{E}-03$ & $5.83 \mathrm{E}-03$ & $5.43 \mathrm{E}-03$ & $6.78 \mathrm{E}-03$ & $6.54 \mathrm{E}-03$ & $6.13 \mathrm{E}-03$ \\
\hline 100 & 1 & $6.61 \mathrm{E}-03$ & $6.38 \mathrm{E}-03$ & $5.94 \mathrm{E}-03$ & $8.10 \mathrm{E}-03$ & 7.86E-03 & 7.41E-03 & $8.84 \mathrm{E}-03$ & $8.60 \mathrm{E}-03$ & $8.14 \mathrm{E}-03$ & $9.59 \mathrm{E}-03$ & $9.34 \mathrm{E}-03$ & $8.88 \mathrm{E}-03$ \\
\hline 100 & 1.5 & $7.56 \mathrm{E}-03$ & $7.35 \mathrm{E}-03$ & $6.94 \mathrm{E}-03$ & 9.07E-03 & $8.86 \mathrm{E}-03$ & $8.44 \mathrm{E}-03$ & $9.83 \mathrm{E}-03$ & $9.61 \mathrm{E}-03$ & 9.19E-03 & $1.06 \mathrm{E}-02$ & $1.04 \mathrm{E}-02$ & $9.94 \mathrm{E}-03$ \\
\hline 100 & 2 & $8.16 \mathrm{E}-03$ & 7.97E-03 & $7.60 \mathrm{E}-03$ & $9.68 \mathrm{E}-03$ & $9.49 \mathrm{E}-03$ & $9.12 \mathrm{E}-03$ & $1.04 \mathrm{E}-02$ & $1.03 \mathrm{E}-02$ & $9.88 \mathrm{E}-03$ & $1.12 \mathrm{E}-02$ & 1.10E-02 & $1.06 \mathrm{E}-02$ \\
\hline 160 & 0.5 & $4.82 \mathrm{E}-03$ & $4.51 \mathrm{E}-03$ & $3.98 \mathrm{E}-03$ & $6.25 \mathrm{E}-03$ & $5.94 \mathrm{E}-03$ & $5.39 \mathrm{E}-03$ & $6.97 \mathrm{E}-03$ & $6.65 \mathrm{E}-03$ & $6.10 \mathrm{E}-03$ & $7.69 \mathrm{E}-03$ & $7.37 \mathrm{E}-03$ & $6.81 \mathrm{E}-03$ \\
\hline 160 & 1 & $7.39 \mathrm{E}-03$ & $7.13 E-03$ & $6.64 \mathrm{E}-03$ & $8.90 \mathrm{E}-03$ & $8.64 \mathrm{E}-03$ & 8.13E-03 & $9.66 \mathrm{E}-03$ & $9.39 \mathrm{E}-03$ & $8.88 \mathrm{E}-03$ & $1.04 \mathrm{E}-02$ & $1.01 \mathrm{E}-02$ & $9.62 \mathrm{E}-03$ \\
\hline 160 & 1.5 & $8.24 \mathrm{E}-03$ & $8.02 \mathrm{E}-03$ & $7.59 \mathrm{E}-03$ & $9.77 \mathrm{E}-03$ & $9.54 \mathrm{E}-03$ & $9.10 \mathrm{E}-03$ & $1.05 \mathrm{E}-02$ & $1.03 \mathrm{E}-02$ & $9.86 \mathrm{E}-03$ & 1.13E-02 & 1.11E-02 & $1.06 \mathrm{E}-02$ \\
\hline 160 & 2 & $8.74 \mathrm{E}-03$ & $8.56 \mathrm{E}-03$ & $8.18 \mathrm{E}-03$ & $1.03 \mathrm{E}-02$ & $1.01 \mathrm{E}-02$ & $9.71 \mathrm{E}-03$ & $1.11 \mathrm{E}-02$ & $1.09 \mathrm{E}-02$ & $1.05 \mathrm{E}-02$ & $1.18 \mathrm{E}-02$ & 1.16E-02 & $1.12 \mathrm{E}-02$ \\
\hline 200 & 0.5 & $5.33 \mathrm{E}-03$ & $4.98 \mathrm{E}-03$ & $4.37 \mathrm{E}-03$ & $6.78 \mathrm{E}-03$ & $6.41 \mathrm{E}-03$ & 5.79E-01 & $7.50 \mathrm{E}-03$ & $7.14 \mathrm{E}-03$ & $6.50 \mathrm{E}-03$ & $8.23 \mathrm{E}-03$ & $7.86 \mathrm{E}-03$ & $7.21 \mathrm{E}-03$ \\
\hline 200 & 1 & $7.79 \mathrm{E}-03$ & $7.52 \mathrm{E}-03$ & $7.00 \mathrm{E}-03$ & $9.31 \mathrm{E}-03$ & $9.03 \mathrm{E}-03$ & $8.50 \mathrm{E}-01$ & $1.01 \mathrm{E}-02$ & $9.79 \mathrm{E}-03$ & $9.25 \mathrm{E}-03$ & $1.08 \mathrm{E}-02$ & $1.05 \mathrm{E}-02$ & $1.00 \mathrm{E}-02$ \\
\hline 200 & 1.5 & 8.57E-03 & $8.34 \mathrm{E}-03$ & 7.90E-03 & $1.01 \mathrm{E}-02$ & $9.88 \mathrm{E}-03$ & $9.43 \mathrm{E}-01$ & 1.09E-02 & $1.06 \mathrm{E}-02$ & $1.02 \mathrm{E}-02$ & 1.16E-02 & $1.14 \mathrm{E}-02$ & $1.10 \mathrm{E}-02$ \\
\hline 200 & 2 & $9.02 \mathrm{E}-03$ & $8.84 \mathrm{E}-03$ & $8.46 \mathrm{E}-03$ & $1.06 \mathrm{E}-02$ & $1.04 \mathrm{E}-02$ & 9.99E-01 & $1.13 \mathrm{E}-02$ & 1.11E-02 & $1.08 \mathrm{E}-02$ & $1.21 \mathrm{E}-02$ & 1.19E-02 & $1.15 \mathrm{E}-02$ \\
\hline
\end{tabular}


Table 2 continued: Dry DV (m/s) evaluated as a function of particle diameter, particle density, surface roughness, wind speed, and atmospheric stability class.

$10 \mu \mathrm{m}$ particle diameter

\begin{tabular}{|c|c|c|c|c|c|c|c|c|c|c|c|c|c|}
\hline \multirow{2}{*}{$\begin{array}{c}\mathrm{Z}_{0} \\
(\mathrm{~cm})\end{array}$} & \multirow{2}{*}{$\begin{array}{c}\text { Wind } \\
\text { Speed } \\
(\mathrm{m} / \mathrm{s})\end{array}$} & \multicolumn{3}{|c|}{$\begin{array}{c}\text { density }=1 \mathrm{~g} / \mathrm{cm}^{3} \\
\text { Stability Class }\end{array}$} & \multicolumn{3}{|c|}{$\begin{array}{l}\text { density }=3 \mathrm{~g} / \mathrm{cm}^{3} \\
\text { Stability Class }\end{array}$} & \multicolumn{3}{|c|}{$\begin{array}{l}\text { density }=4 \mathrm{~g} / \mathrm{cm}^{3} \\
\text { Stability Class }\end{array}$} & \multicolumn{3}{|c|}{$\begin{array}{c}\text { density }=5 \mathrm{~g} / \mathrm{cm}^{3} \\
\text { Stability Class }\end{array}$} \\
\hline & & D & $\mathrm{E}$ & $\mathrm{F}$ & D & $E$ & $\mathrm{~F}$ & D & $E$ & $\mathrm{~F}$ & D & $E$ & $\mathrm{~F}$ \\
\hline 3 & 0.5 & $3.67 \mathrm{E}-03$ & $3.60 \mathrm{E}-03$ & $3.45 \mathrm{E}-03$ & $.56 \mathrm{E}-03$ & $9.51 \mathrm{E}-03$ & $9.41 \mathrm{E}-03$ & $1.26 \mathrm{E}-02$ & $1.25 \mathrm{E}-02$ & $1.24 \mathrm{E}-02$ & $1.56 \mathrm{E}-02$ & $1.55 \mathrm{E}-02$ & $1.55 \mathrm{E}-02$ \\
\hline 3 & 1 & $5.20 \mathrm{E}-03$ & $5.02 \mathrm{E}-03$ & 4.59E-03 & $1.09 \mathrm{E}-02$ & 1.07E-02 & $1.03 \mathrm{E}-02$ & $1.38 \mathrm{E}-02$ & 1.36E-02 & $1.32 \mathrm{E}-02$ & 1.67E-02 & 1.65E-02 & $1.62 \mathrm{E}-02$ \\
\hline 3 & 1.5 & $6.08 \mathrm{E}-03$ & $5.86 \mathrm{E}-03$ & $5.32 \mathrm{E}-03$ & $1.18 \mathrm{E}-02$ & 1.16E-02 & $1.10 \mathrm{E}-02$ & 1.47E-02 & $1.44 \mathrm{E}-02$ & 1.39E-02 & 1.76E-02 & 1.74E-02 & $1.68 \mathrm{E}-02$ \\
\hline 3 & 2 & $6.79 \mathrm{E}-03$ & $6.55 \mathrm{E}-03$ & $5.94 \mathrm{E}-03$ & $1.25 \mathrm{E}-02$ & $1.23 \mathrm{E}-02$ & 1.17E-02 & $1.54 \mathrm{E}-02$ & $1.52 \mathrm{E}-02$ & $1.45 \mathrm{E}-02$ & $1.83 \mathrm{E}-02$ & $1.81 \mathrm{E}-02$ & $1.75 \mathrm{E}-02$ \\
\hline 30 & 0.5 & $4.65 \mathrm{E}-03$ & $4.48 \mathrm{E}-03$ & 4.19E-03 & 1.04E-02 & $1.02 \mathrm{E}-02$ & $9.97 \mathrm{E}-03$ & $1.33 \mathrm{E}-02$ & $1.32 \mathrm{E}-02$ & $1.29 \mathrm{E}-02$ & $1.62 \mathrm{E}-02$ & $1.61 \mathrm{E}-02$ & $1.59 \mathrm{E}-02$ \\
\hline 30 & 1 & 7.10E-03 & $6.84 \mathrm{E}-03$ & $6.32 \mathrm{E}-03$ & $1.28 \mathrm{E}-02$ & $1.25 \mathrm{E}-02$ & $1.20 \mathrm{E}-02$ & 1.57E-02 & $1.54 \mathrm{E}-02$ & $1.49 \mathrm{E}-02$ & $1.86 \mathrm{E}-02$ & $1.83 \mathrm{E}-02$ & $1.78 \mathrm{E}-02$ \\
\hline 30 & 1.5 & $8.18 \mathrm{E}-03$ & 7.91E-03 & 7.36E-03 & $1.40 \mathrm{E}-02$ & $1.37 \mathrm{E}-02$ & $1.31 \mathrm{E}-02$ & $1.69 \mathrm{E}-02$ & 1.66E-02 & $1.60 \mathrm{E}-02$ & 1.99E-02 & 1.96E-02 & $1.89 \mathrm{E}-02$ \\
\hline 30 & 2 & 8.93E-03 & 8.67E-03 & 8.13E-03 & $1.48 \mathrm{E}-02$ & $1.45 \mathrm{E}-02$ & $1.40 \mathrm{E}-02$ & $1.78 \mathrm{E}-02$ & $1.75 \mathrm{E}-02$ & $1.69 \mathrm{E}-02$ & 2.07E-02 & $2.04 \mathrm{E}-02$ & $1.98 \mathrm{E}-02$ \\
\hline 100 & 0.5 & $6.02 \mathrm{E}-03$ & $5.78 \mathrm{E}-03$ & $5.38 \mathrm{E}-03$ & 1.17E-02 & $1.14 \mathrm{E}-02$ & $1.10 \mathrm{E}-02$ & $1.46 \mathrm{E}-02$ & $1.43 \mathrm{E}-02$ & $1.39 \mathrm{E}-02$ & $1.75 \mathrm{E}-02$ & $1.72 \mathrm{E}-02$ & $1.69 \mathrm{E}-02$ \\
\hline 100 & 1 & 8.79E-03 & $8.55 \mathrm{E}-03$ & 8.09E-03 & 1.47E-02 & $1.44 \mathrm{E}-02$ & $1.39 \mathrm{E}-02$ & 1.76E-02 & $1.73 \mathrm{E}-02$ & $1.68 \mathrm{E}-02$ & $2.06 \mathrm{E}-02$ & $2.03 \mathrm{E}-02$ & $1.98 \mathrm{E}-02$ \\
\hline 100 & 1.5 & $9.78 \mathrm{E}-03$ & $9.56 \mathrm{E}-03$ & $9.14 \mathrm{E}-03$ & $1.58 \mathrm{E}-02$ & $1.55 \mathrm{E}-02$ & $1.51 \mathrm{E}-02$ & 1.87E-02 & $1.85 \mathrm{E}-02$ & $1.80 \mathrm{E}-02$ & 2.17E-02 & 2.15E-02 & 2.10E-02 \\
\hline 100 & 2 & $1.04 \mathrm{E}-02$ & $1.02 \mathrm{E}-02$ & $9.83 \mathrm{E}-03$ & $1.64 \mathrm{E}-02$ & $1.62 \mathrm{E}-02$ & $1.58 \mathrm{E}-02$ & $1.94 \mathrm{E}-02$ & $1.92 \mathrm{E}-02$ & $1.88 \mathrm{E}-02$ & $2.24 \mathrm{E}-02$ & $2.22 \mathrm{E}-02$ & $2.18 \mathrm{E}-02$ \\
\hline 160 & 0.5 & $6.92 \mathrm{E}-03$ & $6.60 \mathrm{E}-03$ & $6.05 \mathrm{E}-03$ & $1.26 \mathrm{E}-02$ & $1.23 \mathrm{E}-02$ & $1.17 \mathrm{E}-02$ & $1.55 \mathrm{E}-02$ & $1.52 \mathrm{E}-02$ & $1.46 \mathrm{E}-02$ & $1.84 \mathrm{E}-02$ & $1.81 \mathrm{E}-02$ & $1.75 \mathrm{E}-02$ \\
\hline 160 & 1 & $9.61 \mathrm{E}-03$ & $9.34 \mathrm{E}-03$ & 8.83E-03 & $1.56 \mathrm{E}-02$ & $1.53 \mathrm{E}-02$ & 1.47E-02 & $1.85 \mathrm{E}-02$ & $1.82 \mathrm{E}-02$ & $1.77 \mathrm{E}-02$ & $2.15 \mathrm{E}-02$ & $2.12 \mathrm{E}-02$ & 2.06E-02 \\
\hline 160 & 1.5 & $1.05 \mathrm{E}-02$ & $1.03 \mathrm{E}-02$ & $9.81 \mathrm{E}-03$ & $1.65 \mathrm{E}-02$ & $1.63 \mathrm{E}-02$ & $1.58 \mathrm{E}-02$ & $1.95 \mathrm{E}-02$ & 1.93E-02 & $1.88 \mathrm{E}-02$ & $2.25 \mathrm{E}-02$ & $2.23 \mathrm{E}-02$ & $2.18 \mathrm{E}-02$ \\
\hline 160 & 2 & 1.10E-02 & $1.08 \mathrm{E}-02$ & $1.04 \mathrm{E}-02$ & $1.71 \mathrm{E}-02$ & 1.69E-02 & $1.64 \mathrm{E}-02$ & $2.01 \mathrm{E}-02$ & 1.99E-02 & $1.95 \mathrm{E}-02$ & $2.31 \mathrm{E}-02$ & $2.29 \mathrm{E}-02$ & $2.25 \mathrm{E}-02$ \\
\hline 200 & 0.5 & $7.45 \mathrm{E}-03$ & $7.09 \mathrm{E}-03$ & $6.45 \mathrm{E}-03$ & $1.32 \mathrm{E}-02$ & $1.28 \mathrm{E}-02$ & $1.21 \mathrm{E}+00$ & $1.61 \mathrm{E}-02$ & $1.57 \mathrm{E}-02$ & $1.50 \mathrm{E}-02$ & $1.90 \mathrm{E}-02$ & $1.86 \mathrm{E}-02$ & $1.79 \mathrm{E}-02$ \\
\hline 200 & 1 & $1.00 \mathrm{E}-02$ & 9.74E-03 & $9.20 \mathrm{E}-03$ & $1.60 \mathrm{E}-02$ & 1.57E-02 & $1.51 \mathrm{E}+00$ & $1.90 \mathrm{E}-02$ & 1.87E-02 & $1.81 \mathrm{E}-02$ & $2.20 \mathrm{E}-02$ & 2.17E-02 & $2.11 \mathrm{E}-02$ \\
\hline 200 & 1.5 & $1.08 \mathrm{E}-02$ & 1.06E-02 & $1.01 \mathrm{E}-02$ & 1.69E-02 & $1.66 \mathrm{E}-02$ & $1.61 \mathrm{E}+00$ & $1.99 \mathrm{E}-02$ & $1.96 \mathrm{E}-02$ & $1.91 \mathrm{E}-02$ & $2.29 \mathrm{E}-02$ & $2.27 \mathrm{E}-02$ & $2.21 \mathrm{E}-02$ \\
\hline 200 & 2 & 1.13E-02 & $1.11 \mathrm{E}-02$ & 1.07E-02 & $1.74 \mathrm{E}-02$ & $1.72 \mathrm{E}-02$ & $1.68 \mathrm{E}+00$ & $2.04 \mathrm{E}-02$ & $2.02 \mathrm{E}-02$ & $1.98 \mathrm{E}-02$ & $2.34 \mathrm{E}-02$ & $2.32 \mathrm{E}-02$ & $2.28 \mathrm{E}-02$ \\
\hline
\end{tabular}




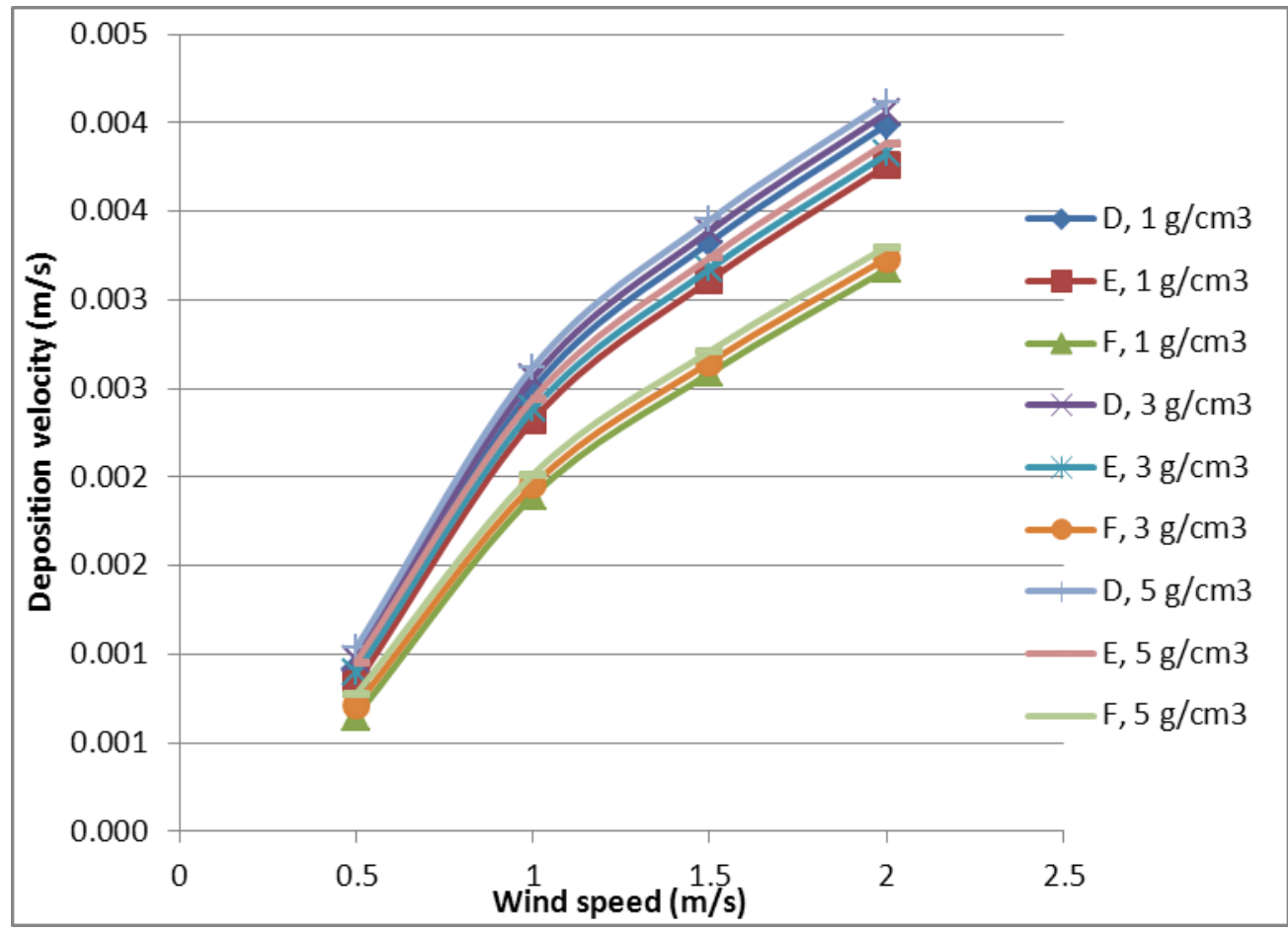

Figure 2. Variation of Dry DV as a Function of Wind Speed, Stability Class, and Particle Density; Developed for $1 \mu \mathrm{m}$ Particles and a Surface Roughness of $0.03 \mathrm{~m}$.

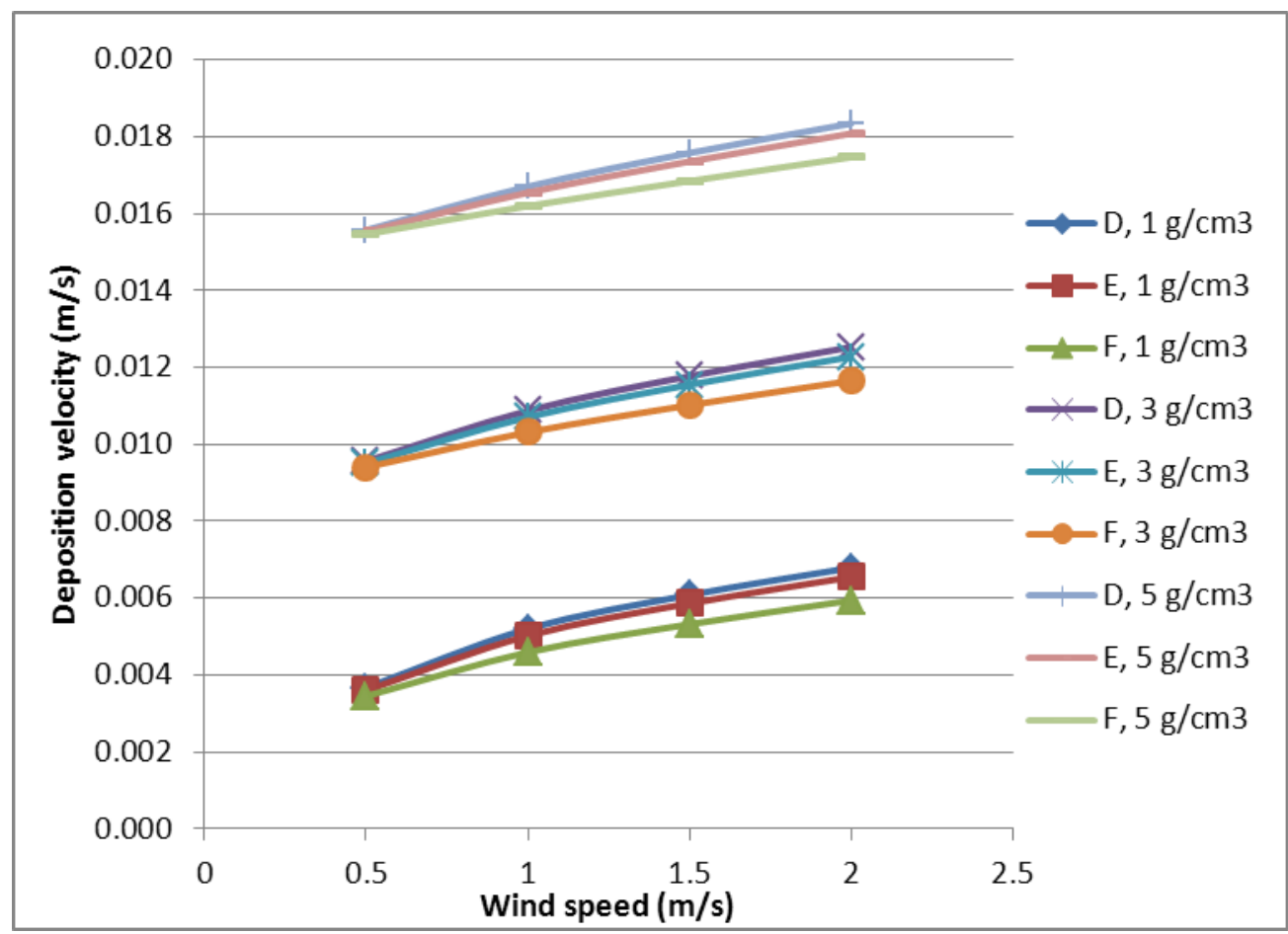

Figure 3. Variation of Dry DV as a Function of Wind Speed, Stability Class, and Particle Density; Developed for $10 \mu \mathrm{m}$ particles and a Surface Roughness of $0.03 \mathrm{~m}$. 


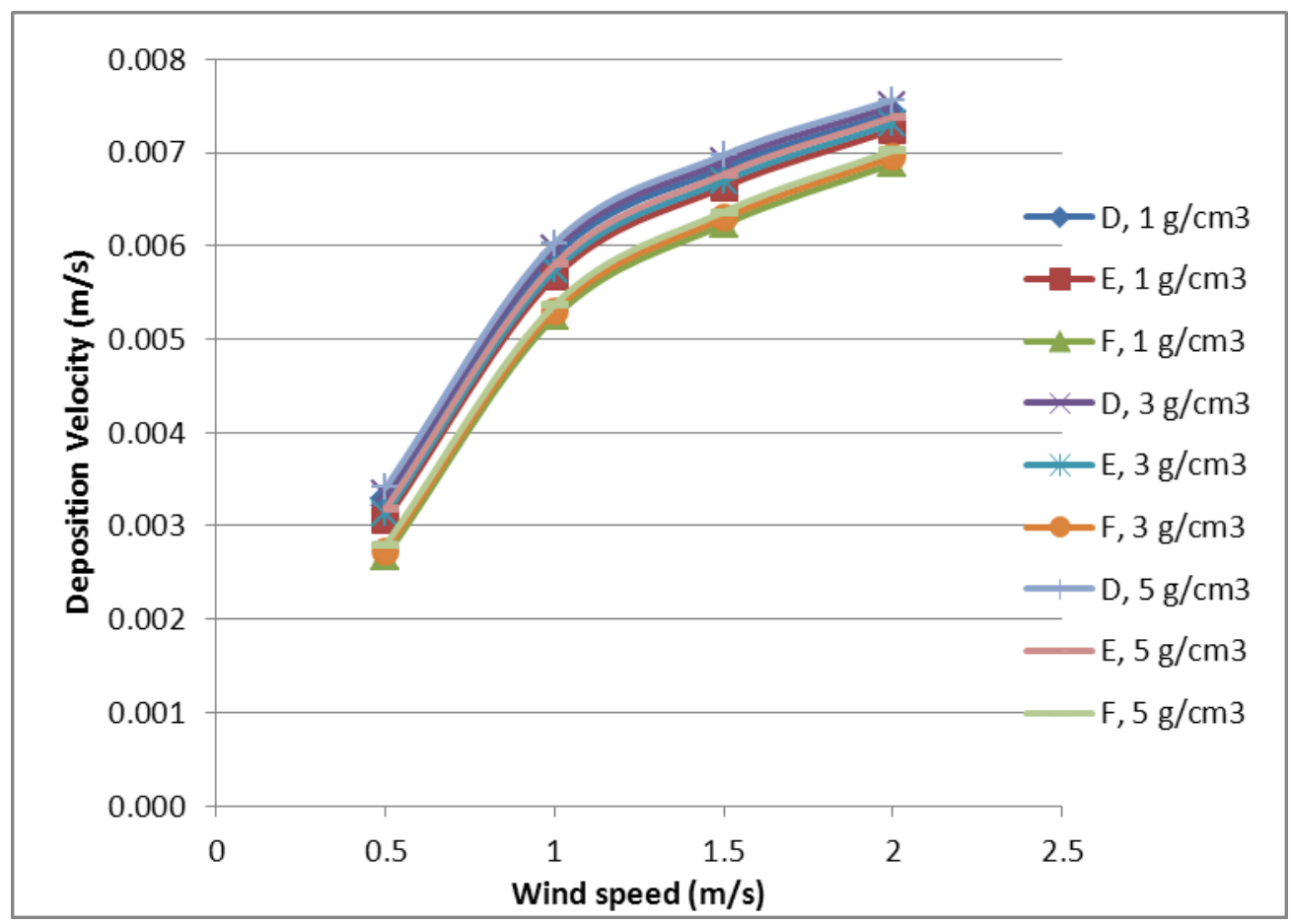

Figure 4. Variation of Dry DV as a Function of Wind Speed, Stability Class, and Particle Density; Developed for $1 \mu \mathrm{m}$ Particles and a Surface Roughness of $1 \mathrm{~m}$.

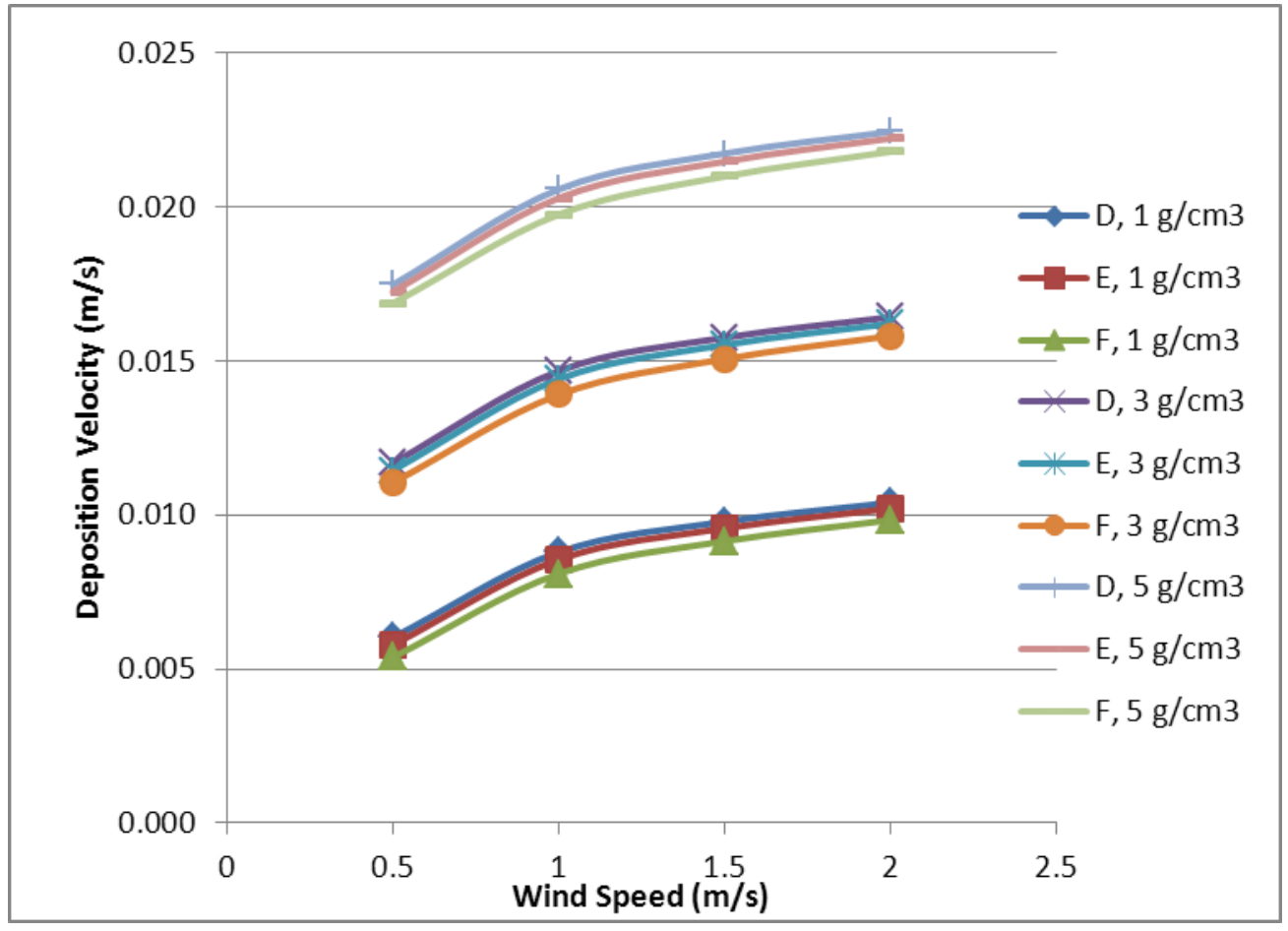

Figure 5. Variation of Dry DV as a Function of Wind Speed, Stability Class, and Particle Density; Developed for $10 \mu \mathrm{m}$ particles and a Surface Roughness of $1 \mathrm{~m}$. 


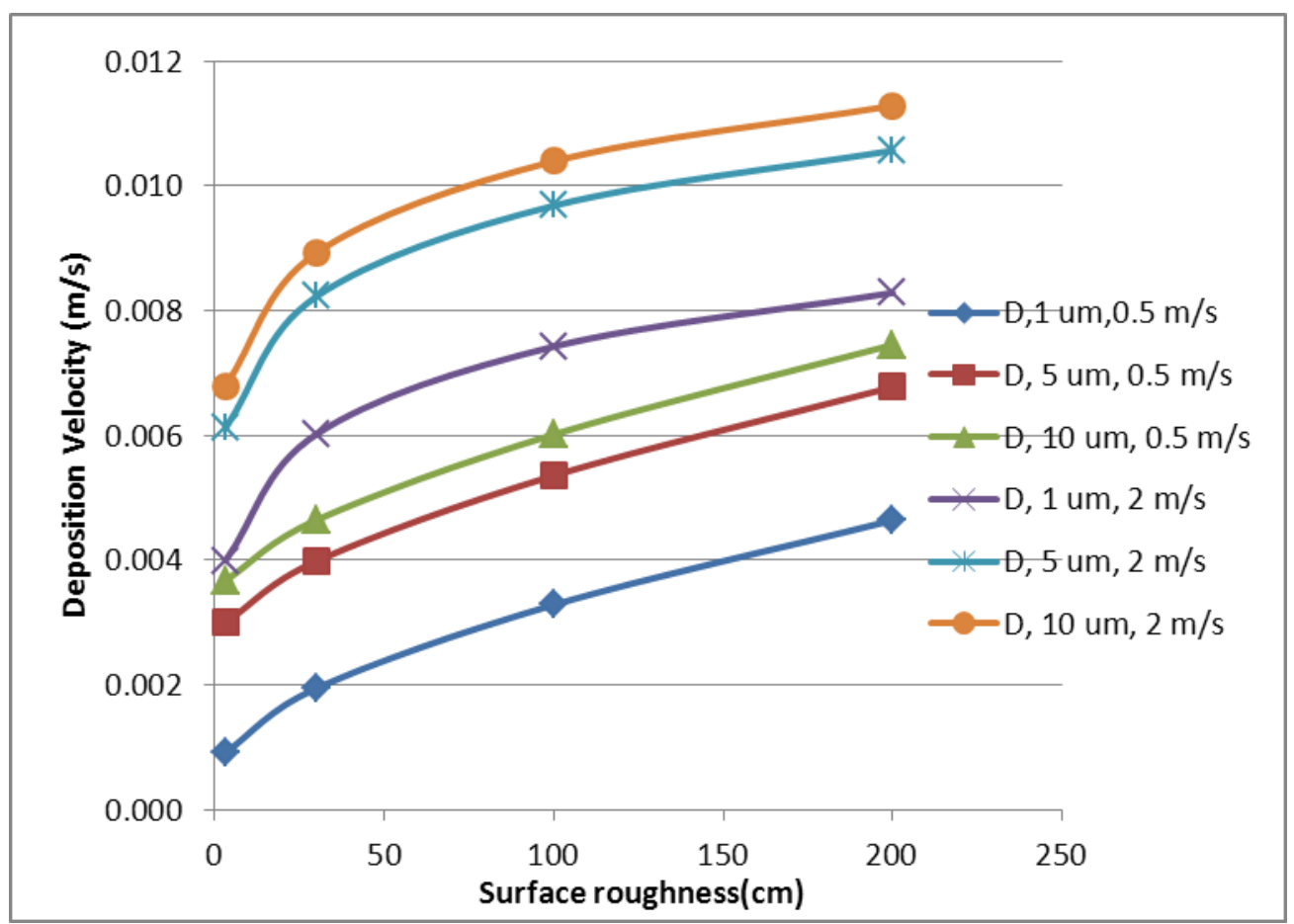

Figure 6. Variation of Dry DV as a Function of Surface Roughness; Developed for Particles of Density 1 $\mathrm{g} / \mathrm{cm}^{3}$, Stability Class D.

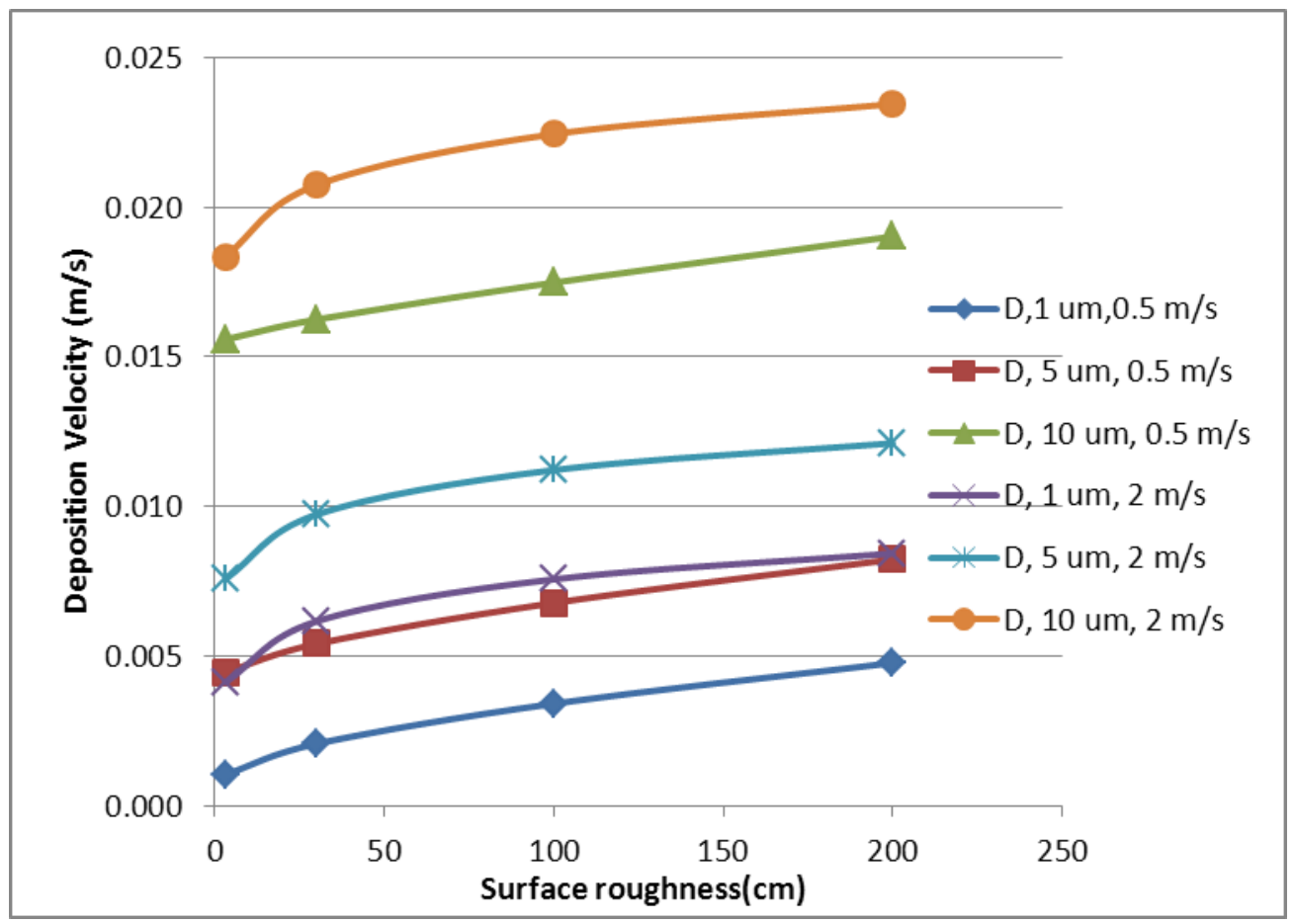

Figure 7. Variation of Dry DV as a Function of Surface Roughness; Developed for Particles of Density 5 $\mathrm{g} / \mathrm{cm}^{3}$, Stability Class D. 


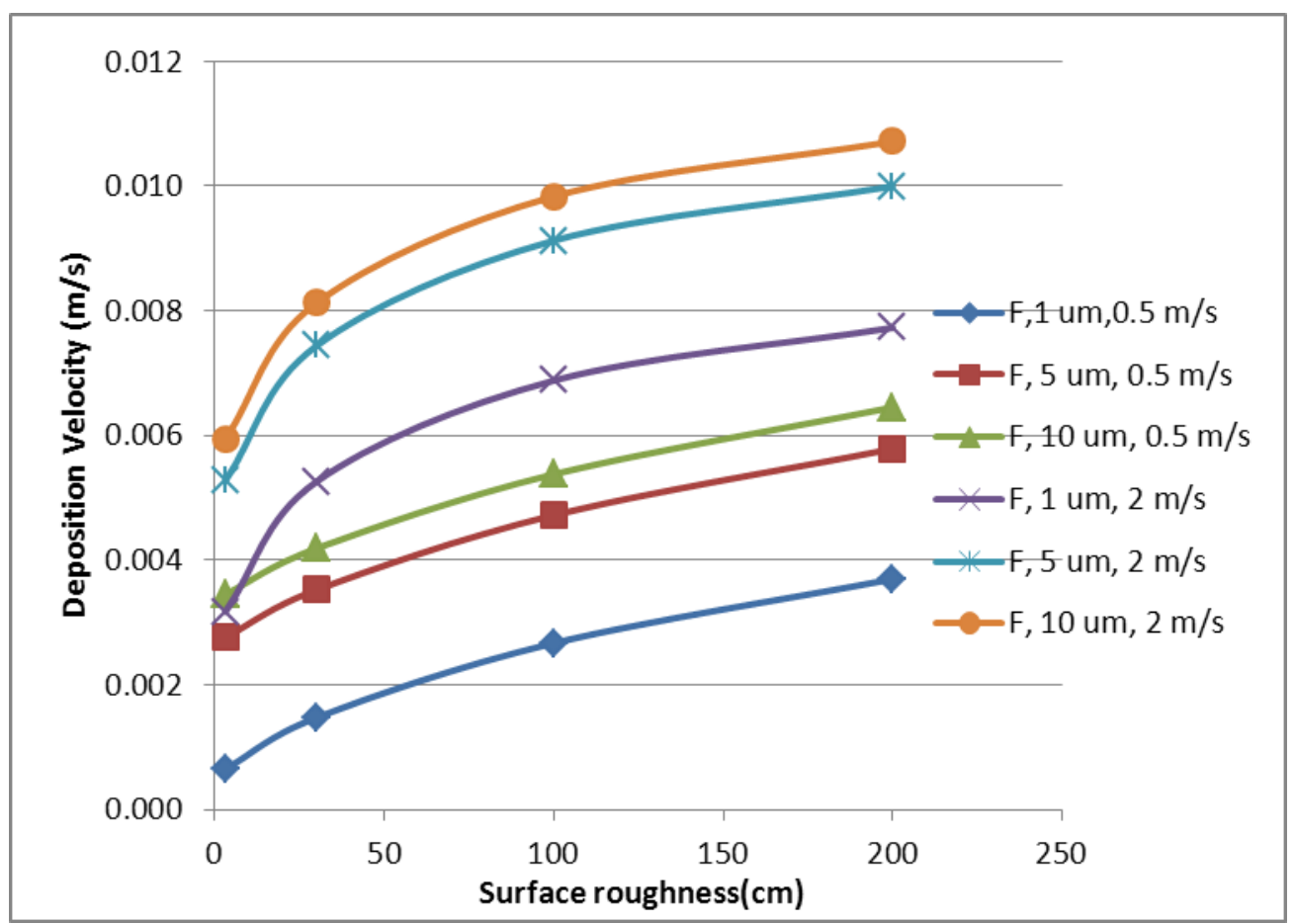

Figure 8. Variation of Dry DV as a Function of Surface Roughness; Developed for Particles of Density 1 $\mathrm{g} / \mathrm{cm}^{3}$, Stability Class F.

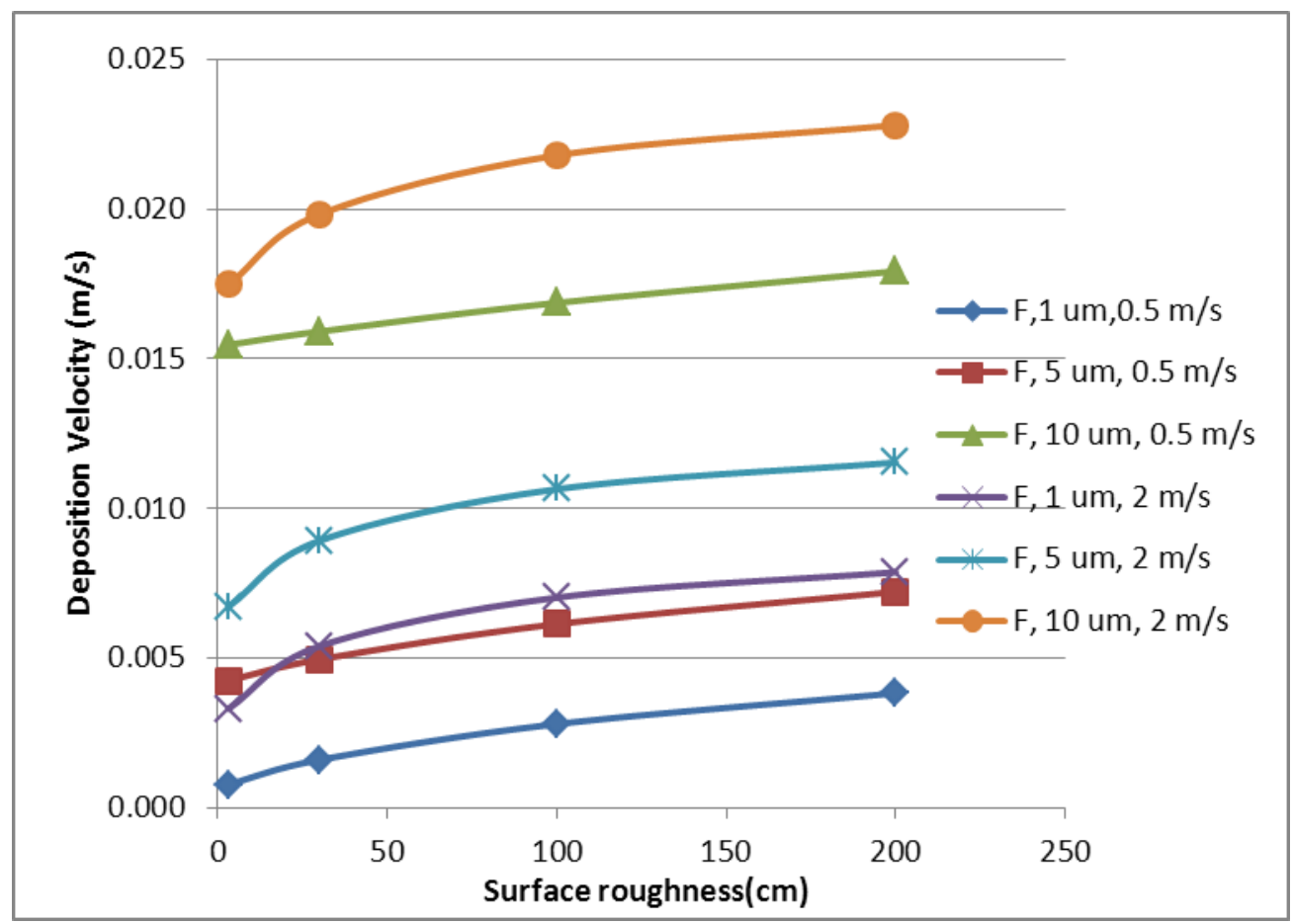

Figure 9. Variation of Dry DV as a Function of Surface Roughness; Developed for Particles of Density 5 $\mathrm{g} / \mathrm{cm}^{3}$, Stability Class F. 


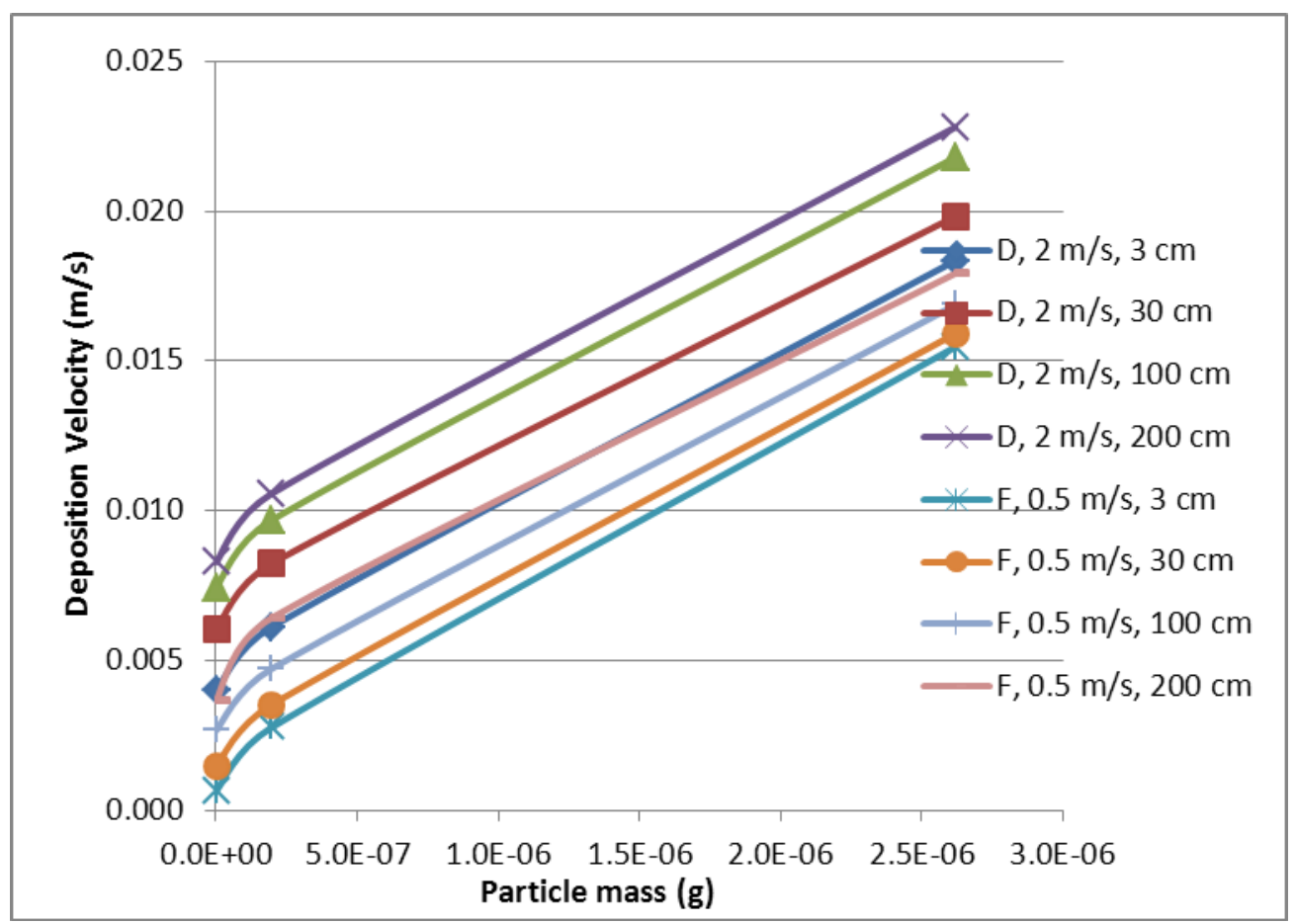

Figure 10. DV as a function of particle mass (volume*density) for various wind speed/stability combinations 


\section{4. $95^{\text {th }}$ Percentile Conditions for Savannah River Site}

The $95^{\text {th }}$ percentile module of the GENII code was run with 5 years' worth of meteorological data collected at the Savannah River Site and processed into the GENII input format (Hunter and Viner 2013). The GENII code is designed to report the $95^{\text {th }}$ percentile, based on air concentration, for a given meteorological data set. As for the parametric studies discussed in Section 3, the $95^{\text {th }}$ percentile air concentration is a function of not only the meteorological conditions but the particle characteristics as well. For this set of calculations, a range of particle sizes were evaluated $(1,5$, and $10 \mu \mathrm{m}$ mass mean diameters) and, for each, a range of particle densities $\left(1,3,4\right.$, and $\left.5 \mathrm{~g} / \mathrm{cm}^{3}\right)$. Because the GENII $95 \%$ module also scans by direction, the intermediate file of hourly results of air concentration, dry and wet deposition, and sky shine was queried instead for each of the combinations of particle size and density, for 10 downwind distances (early calculations showed essentially no difference in the results at 9200, 9300, and 9400 meters, so the 9300 meter distance was omitted in the calculations). This procedure produced a total of 120 results. The dry deposition velocity was extracted by definition as the quotient of the standard GENII outputs of total deposition $\left(\mathrm{Bq} / \mathrm{m}^{2}\right)$ divided by the integrated air concentration (Bq$\mathrm{sec} / \mathrm{m}^{3}$ ); because source term is divided out with this procedure, a unit acute release of one $\mathrm{Bq}$ was used.

The calculations, and reviews, followed the procedures of the GENII Quality Assurance Manual (PNNL 2013). The records of the calculations are stored in the project records. The general approach to Software Quality Assurance is discussed in Section 6.

The calculations are summarized in Table 3. This table provides the dry deposition velocity that corresponds to the $95^{\text {th }}$ percentile concentration of contaminant, independent of direction, for Savannah River Site conditions. A single surface roughness of $160 \mathrm{~cm}$ was used in all calculations, as recommended by Weber et al. (2012).

Note that the wind speeds provided are those measured at the 61-meter height on the SRS towers. The wind speeds may be adjusted to ground level using the GENII diabatic wind profile (Eq. 4). Using this technique, equivalent 10-meter wind speeds can be found. As a comparison, the power-function algorithm used by Hunter and Viner (2013) may also be used. The estimated wind speed at 10 meters height for each stability/61-meter wind speed combination is given in Table 4. As can be seen from Table 4, the $10-\mathrm{m}$ (ground-level) wind speed is between $1 / 3$ and $1 / 2$ of the upper-level wind. The GENII and Hunter and Viner (2013) values are similar to GENII's for stability class F, and within $20 \%$ for class E and $50 \%$ for class D. As can be seen, the generic recommendation by Hunter and Viner (2013) of representative values of Class $\mathrm{F}$ and $1.3 \mathrm{~m} / \mathrm{s}$ is not unreasonable for very small or light particles, but is overly conservative for large heavy particles.

The results are presented graphically in Figure 11, which illustrates the entire data set in a single figure. From either Table 3 or Figure 11, it can be seen that the DV increases slightly with increasing distance. This is a direct result of the influence of Eq. 10 on the downwind air concentrations. At distances greater than about 8000 meters, the wind speed corresponding to the $95^{\text {th }}$ percentile concentration is about $50 \%$ greater than the wind speed corresponding to the $95^{\text {th }}$ percentile at shorter distances. As a result, as can be seen from Table 3, for particles greater than 1 micron in diameter, the associated stability class has decreased by one class, or by two classes for the very large, dense particles. 
Table 3. Dry deposition velocity (DV, $\mathrm{m} / \mathrm{s}$ ) for $95^{\text {th }}$ percentile Savannah River Site conditions as a function of downwind distance, with associated 61-meter wind speed, stability category, and $\chi / \mathrm{Q}$ for multiple combinations of particle size and density.

\begin{tabular}{|c|c|c|c|c|c|c|c|c|c|c|}
\hline & $1 \mathrm{lg}$ & & & & & & & & & \\
\hline Distance (m) & 670 & 5200 & 8900 & 9200 & 9400 & 10000 & 10500 & 10900 & 11200 & 11500 \\
\hline $\mathrm{DV}(\mathrm{m} / \mathrm{s})$ & $6.17 \mathrm{E}-03$ & $6.10 \mathrm{E}-03$ & $4.86 \mathrm{E}-03$ & $6.92 \mathrm{E}-03$ & $6.92 \mathrm{E}-03$ & $6.92 \mathrm{E}-03$ & $6.86 \mathrm{E}-03$ & $6.86 \mathrm{E}-03$ & $6.87 \mathrm{E}-03$ & $6.87 \mathrm{E}-03$ \\
\hline Stability & $\mathrm{F}$ & $\mathrm{F}$ & $\mathrm{F}$ & $\mathrm{F}$ & $\mathrm{F}$ & $\mathrm{F}$ & $\mathrm{F}$ & $\mathrm{F}$ & $\mathrm{F}$ & $\mathrm{F}$ \\
\hline Speed $(\mathrm{m} / \mathrm{s})$ & 3.1 & 3.0 & 2.1 & 4.3 & 4.3 & 4.3 & 4.2 & 4.2 & 4.2 & 4.2 \\
\hline \multirow[t]{2}{*}{$x / Q\left(s / m^{3}\right)$} & $6.84 \mathrm{E}-04$ & 1.10E-05 & 4.03E-06 & $3.78 \mathrm{E}-06$ & $3.64 \mathrm{E}-06$ & $3.23 \mathrm{E}-06$ & $2.93 \mathrm{E}-06$ & $2.73 \mathrm{E}-06$ & $2.58 \mathrm{E}-06$ & $2.45 \mathrm{E}-06$ \\
\hline & $1 \mathrm{um} 3 \mathrm{~g} / \mathrm{cc}$ & & & & & & & & & \\
\hline Distance (m) & 670 & 5200 & 8900 & 9200 & 9400 & 10000 & 10500 & 10900 & 11200 & 11500 \\
\hline $\mathrm{DV}(\mathrm{m} / \mathrm{s})$ & $6.24 \mathrm{E}-03$ & $6.16 \mathrm{E}-03$ & $6.99 \mathrm{E}-03$ & $6.98 \mathrm{E}-03$ & $6.98 \mathrm{E}-03$ & $6.93 \mathrm{E}-03$ & $6.93 \mathrm{E}-03$ & $6.93 \mathrm{E}-03$ & $6.93 \mathrm{E}-03$ & $6.93 \mathrm{E}-03$ \\
\hline Stability & $\mathrm{F}$ & $\mathrm{F}$ & $\mathrm{F}$ & $\mathrm{F}$ & $\mathrm{F}$ & $\mathrm{F}$ & $\mathrm{F}$ & $\mathrm{F}$ & $\mathrm{F}$ & $\mathrm{F}$ \\
\hline Speed $(\mathrm{m} / \mathrm{s})$ & 3.1 & 3.0 & 4.3 & 4.3 & 4.3 & 4.2 & 4.2 & 4.2 & 4.2 & 4.2 \\
\hline \multirow[t]{2}{*}{$\chi / Q\left(s / m^{3}\right)$} & $6.80 e-04$ & $1.08 \mathrm{e}-05$ & $3.96 \mathrm{E}-06$ & $3.72 \mathrm{E}-06$ & $3.58 \mathrm{E}-06$ & $3.16 \mathrm{E}-06$ & $2.88 \mathrm{E}-06$ & $2.68 \mathrm{E}-06$ & $2.54 \mathrm{E}-06$ & $2.41 \mathrm{E}-06$ \\
\hline & $1 \mathrm{um} 4 \mathrm{~g} / \mathrm{cc}$ & & & & & & & & & \\
\hline Distance (m) & 670 & 5200 & 8900 & 9200 & 9400 & 10000 & 10500 & 10900 & 11200 & 11500 \\
\hline $\mathrm{DV}(\mathrm{m} / \mathrm{s})$ & $6.27 \mathrm{E}-03$ & $6.20 \mathrm{E}-03$ & $7.02 \mathrm{E}-03$ & $7.02 \mathrm{E}-03$ & $7.02 \mathrm{E}-03$ & 6.97E-03 & $6.97 E-03$ & $6.97 \mathrm{E}-03$ & $6.97 \mathrm{E}-03$ & $6.97 \mathrm{E}-03$ \\
\hline Stability & $\mathrm{F}$ & $\mathrm{F}$ & $\mathrm{F}$ & $\mathrm{F}$ & $\mathrm{F}$ & $\mathrm{F}$ & $\mathrm{F}$ & $\mathrm{F}$ & $\mathrm{F}$ & $\mathrm{F}$ \\
\hline Speed $(\mathrm{m} / \mathrm{s})$ & 3.1 & 3.0 & 4.3 & 4.3 & 4.3 & 4.2 & 4.2 & 4.2 & 4.2 & 4.2 \\
\hline \multirow[t]{2}{*}{$\chi / Q\left(s / m^{3}\right)$} & $6.78 \mathrm{E}-04$ & $1.08 \mathrm{E}-05$ & 3.93E-06 & $3.69 \mathrm{E}-06$ & $3.55 E-06$ & $3.14 \mathrm{E}-06$ & $2.85 \mathrm{E}-06$ & $2.65 \mathrm{E}-06$ & $2.51 \mathrm{E}-06$ & $2.39 \mathrm{E}-06$ \\
\hline & $1 \mathrm{um} 5 \mathrm{~g} / \mathrm{cc}$ & & & & & & & & & \\
\hline Distance (m) & 670 & 5200 & 8900 & 9200 & 9400 & 10000 & 10500 & 10900 & 11200 & 11500 \\
\hline $\mathrm{DV}(\mathrm{m} / \mathrm{s})$ & $6.31 \mathrm{E}-03$ & $6.15 \mathrm{E}-03$ & 7.05E-03 & 7.05E-03 & 7.05E-03 & 7.00E-03 & $7.00 \mathrm{E}-03$ & $7.00 \mathrm{E}-03$ & $7.00 \mathrm{E}-03$ & 7.00E-03 \\
\hline Stability & $\mathrm{F}$ & $\mathrm{F}$ & $\mathrm{F}$ & $\mathrm{F}$ & $\mathrm{F}$ & $\mathrm{F}$ & $\mathrm{F}$ & $\mathrm{F}$ & $\mathrm{F}$ & $\mathrm{F}$ \\
\hline Speed $(\mathrm{m} / \mathrm{s})$ & 3.1 & 3.0 & 4.3 & 4.3 & 4.3 & 4.2 & 4.2 & 4.2 & 4.2 & 4.2 \\
\hline$\chi / Q\left(s / m^{3}\right)$ & $6.76 \mathrm{E}-04$ & $1.06 \mathrm{E}-05$ & $3.90 \mathrm{E}-06$ & $3.66 \mathrm{E}-06$ & $3.52 \mathrm{E}-06$ & $3.11 \mathrm{E}-06$ & $2.83 \mathrm{E}-06$ & $2.63 \mathrm{E}-06$ & $2.49 \mathrm{E}-06$ & $2.36 \mathrm{E}-06$ \\
\hline
\end{tabular}


Table 3, Continued. Dry deposition velocity (DV, m/s) for $95^{\text {th }}$ percentile Savannah River Site conditions as a function of downwind distance, with associated 61- meter wind speed, stability category, and $\chi / \mathrm{Q}$ for multiple combinations of particle size and density.

5um 1g/cc

\begin{tabular}{|c|c|c|c|c|c|c|c|c|c|c|}
\hline \\
\hline Distance (m) & 670 & 5200 & 8900 & 9200 & 9400 & 10000 & 10500 & 10900 & 11200 & 11500 \\
\hline $\mathrm{DV}(\mathrm{m} / \mathrm{s})$ & $6.88 \mathrm{E}-03$ & $7.48 \mathrm{E}-03$ & 7.53E-03 & 7.53E-03 & 7.53E-03 & $7.53 \mathrm{E}-03$ & 7.53E-03 & 7.53E-03 & 7.53E-03 & $.53 \mathrm{E}-03$ \\
\hline Stability & $\mathrm{F}$ & $\mathrm{F}$ & $\mathrm{F}$ & $\mathrm{F}$ & $\mathrm{F}$ & $\mathrm{F}$ & $\mathrm{F}$ & $\mathrm{F}$ & $\mathrm{F}$ & $\mathrm{F}$ \\
\hline Speed $(\mathrm{m} / \mathrm{s})$ & 3.1 & 4.0 & 4.1 & 4.1 & 4.1 & 4.1 & 4.1 & 4.1 & 4.1 & 4.1 \\
\hline$x / Q\left(s / m^{3}\right)$ & $6.39 \mathrm{E}-04$ & $9.39 \mathrm{E}-06$ & $3.34 \mathrm{E}-06$ & $3.13 \mathrm{E}-06$ & $3.00 \mathrm{E}-06$ & $2.65 \mathrm{E}-06$ & $2.40 \mathrm{E}-06$ & $2.22 \mathrm{E}-06$ & $2.10 \mathrm{E}-06$ & $1.99 \mathrm{E}-06$ \\
\hline \multicolumn{11}{|c|}{5 um $3 g / c c$} \\
\hline Distance (m) & 670 & 5200 & 8900 & 9200 & 9400 & 10000 & 10500 & 10900 & 11200 & 11500 \\
\hline $\mathrm{DV}(\mathrm{m} / \mathrm{s})$ & 8.39E-03 & $8.94 \mathrm{E}-03$ & 8.93E-03 & $9.46 \mathrm{E}-03$ & $9.52 \mathrm{E}-03$ & $9.63 \mathrm{E}-03$ & $9.63 \mathrm{E}-03$ & $9.69 \mathrm{E}-03$ & $9.83 \mathrm{E}-03$ & $9.74 \mathrm{E}-03$ \\
\hline Stability & $\mathrm{F}$ & $\mathrm{F}$ & $\mathrm{F}$ & $\mathrm{E}$ & $E$ & $\mathrm{E}$ & $\mathrm{E}$ & $\mathrm{E}$ & $\mathrm{E}$ & E \\
\hline Speed $(\mathrm{m} / \mathrm{s})$ & 3.1 & 4.0 & 3.9 & 3.3 & 3.4 & 3.6 & 3.6 & 4.0 & 4.1 & 3.8 \\
\hline$x / Q\left(s / m^{3}\right)$ & $5.54 \mathrm{E}-04$ & $6.93 \mathrm{E}-06$ & $2.22 \mathrm{E}-06$ & 2.07E-06 & $2.00 \mathrm{E}-06$ & $1.80 \mathrm{E}-06$ & $1.66 \mathrm{E}-06$ & 1.57E-06 & 1.50E-06 & $1.43 \mathrm{E}-06$ \\
\hline \multicolumn{11}{|c|}{5 um $4 g / c c$} \\
\hline Distance (m) & 670 & 5200 & 8900 & 9200 & 9400 & 10000 & 10500 & 10900 & 11200 & 11500 \\
\hline $\mathrm{DV}(\mathrm{m} / \mathrm{s})$ & $9.14 \mathrm{E}-03$ & $6.11 \mathrm{E}-03$ & $1.06 \mathrm{E}-02$ & $1.04 \mathrm{E}-02$ & $1.06 \mathrm{E}-02$ & $1.06 \mathrm{E}-02$ & 1.09E-02 & 1.07E-02 & 1.07E-02 & 1.10E-02 \\
\hline Stability & $\mathrm{F}$ & D & $\mathrm{E}$ & $\mathrm{E}$ & $\mathrm{E}$ & $\mathrm{E}$ & $\mathrm{E}$ & $E$ & $E$ & $\mathrm{E}$ \\
\hline Speed $(\mathrm{m} / \mathrm{s})$ & 3.1 & 0.8 & 3.9 & 3.7 & 4.1 & 3.9 & 4.6 & 4.1 & 4.2 & 5.0 \\
\hline$x / Q\left(s / m^{3}\right)$ & $5.16 \mathrm{E}-04$ & 5.91E-06 & $1.99 \mathrm{E}-06$ & $1.88 \mathrm{E}-06$ & $1.82 \mathrm{E}-06$ & $1.64 \mathrm{E}-06$ & $1.52 \mathrm{E}-06$ & $1.43 \mathrm{E}-06$ & 1.37E-06 & $1.31 \mathrm{E}-06$ \\
\hline \multicolumn{11}{|c|}{5 um $5 g / c c$} \\
\hline Distance (m) & 670 & 5200 & 8900 & 9200 & 9400 & 10000 & 10500 & 10900 & 11200 & 11500 \\
\hline $\mathrm{DV}(\mathrm{m} / \mathrm{s})$ & $9.89 \mathrm{E}-03$ & $1.04 \mathrm{E}-02$ & $1.14 \mathrm{E}-02$ & $1.14 \mathrm{E}-02$ & 1.17E-02 & $1.15 \mathrm{E}-02$ & 1.15E-02 & 1.16E-02 & 1.16E-02 & $1.20 \mathrm{E}-02$ \\
\hline Stability & $\mathrm{F}$ & $\mathrm{F}$ & $E$ & $E$ & $E$ & $E$ & $E$ & $E$ & $E$ & $\mathrm{E}$ \\
\hline Speed $(\mathrm{m} / \mathrm{s})$ & 3.1 & 3.8 & 4.0 & 4.2 & 4.8 & 4.3 & 4.4 & 4.5 & 4.5 & 5.8 \\
\hline$\chi / Q\left(s / m^{3}\right)$ & $4.81 \mathrm{E}-04$ & $5.03 \mathrm{E}-06$ & $1.83 \mathrm{E}-06$ & 1.73E-06 & 1.67E-06 & $1.51 \mathrm{E}-06$ & $1.40 \mathrm{E}-06$ & $1.32 \mathrm{E}-06$ & $1.26 \mathrm{E}-06$ & $1.21 \mathrm{E}-06$ \\
\hline
\end{tabular}


Table 3, Continued. Dry deposition velocity (DV, m/s) for $95^{\text {th }}$ percentile Savannah River Site conditions as a function of downwind distance, with associated 61- meter wind speed, stability category, and $\chi / \mathrm{Q}$ for multiple combinations of particle size and density.

\section{0um $1 \mathrm{~g} / \mathrm{cc}$}

\begin{tabular}{|c|c|c|c|c|c|c|c|c|c|c|}
\hline Distance (m) & 670 & 5200 & 8900 & 9200 & 9400 & 10000 & 10500 & 10900 & 11200 & 11500 \\
\hline $\mathrm{DV}(\mathrm{m} / \mathrm{s})$ & $9.08 \mathrm{E}-03$ & 06E-03 & 05E-02 & $.05 \mathrm{E}-02$ & $.04 \mathrm{E}-02$ & $.05 \mathrm{E}-02$ & $.08 \mathrm{E}-02$ & $.06 \mathrm{E}-02$ & $.09 \mathrm{E}-02$ & $.06 \mathrm{E}-02$ \\
\hline Stability & $\mathrm{F}$ & D & $E$ & $E$ & $E$ & $E$ & $E$ & $E$ & $E$ & $E$ \\
\hline Speed $(\mathrm{m} / \mathrm{s})$ & 3.1 & 0.8 & 3.9 & 3.9 & 3.7 & $3 . .9$ & 4.5 & 4.1 & 4.8 & 4.2 \\
\hline$\chi / Q$ (s) & $5.12 \mathrm{E}-04$ & 97E-06 & O0E-06 & $90 \mathrm{E}-06$ & $.83 \mathrm{E}-06$ & $.65 \mathrm{E}-06$ & $.53 \mathrm{E}-06$ & $.44 \mathrm{E}-06$ & $.38 \mathrm{E}-06$ & $.32 \mathrm{E}-06$ \\
\hline \multicolumn{11}{|c|}{$10 \mathrm{um} 3 \mathrm{~g} / \mathrm{cc}$} \\
\hline Distance (m) & 670 & 5200 & 8900 & 9200 & 9400 & 10000 & 10500 & 10900 & 11200 & 11500 \\
\hline $\mathrm{DV}(\mathrm{m} / \mathrm{s})$ & $1.52 \mathrm{E}-02$ & $69 \mathrm{E}-02$ & $.69 \mathrm{E}-02$ & $.69 \mathrm{E}-02$ & $1.69 \mathrm{E}-02$ & 1.69E-02 & 1.69E-02 & 1.69E-02 & $.69 \mathrm{E}-02$ & 1.69E-02 \\
\hline Stability & $\mathrm{F}$ & $E$ & $E$ & E & $E$ & $E$ & E & $E$ & $E$ & $E$ \\
\hline Speed $(\mathrm{m} / \mathrm{s})$ & 3.3 & 4.6 & 4.6 & 4.6 & 4.6 & 4.6 & 4.6 & 4.6 & 4.6 & 4.6 \\
\hline$x / Q(s / m 3)$ & $2.98 \mathrm{E}-04$ & $94 \mathrm{E}-06$ & 10E-06 & 04E-06 & $9.95 \mathrm{E}-07$ & $8.86 \mathrm{E}-07$ & 8.07E-07 & 7.51E-07 & 7.13E-07 & 6.77E-07 \\
\hline \multicolumn{11}{|c|}{ um $4 \mathrm{~g} / \mathrm{cc}$} \\
\hline Distance (m) & 670 & 5200 & 8900 & 9200 & 9400 & 10000 & 10500 & 10900 & 11200 & 11500 \\
\hline $\mathrm{DV}(\mathrm{m} / \mathrm{s})$ & $1.85 \mathrm{E}-02$ & $99 \mathrm{E}-02$ & 99E-02 & 99E-02 & 99E-02 & $.99 \mathrm{E}-02$ & $.99 \mathrm{E}-02$ & 1.99E-02 & $.99 \mathrm{E}-02$ & $1.99 \mathrm{E}-02$ \\
\hline Stability & $\mathrm{F}$ & $E$ & $E$ & $E$ & $E$ & $E$ & $E$ & $\mathrm{E}$ & $E$ & $E$ \\
\hline Speed $(\mathrm{m} / \mathrm{s})$ & 3.8 & 4.6 & 4.6 & 4.6 & 4.6 & 4.6 & 4.6 & 4.6 & 4.6 & 4.6 \\
\hline x/Q (s/m3) & $2.39 \mathrm{E}-04$ & $34 \mathrm{E}-06$ & $23 \mathrm{E}-07$ & 7.70E-07 & 7.37E-07 & $.49 \mathrm{E}-07$ & $.87 E-07$ & $.43 \mathrm{E}-07$ & $13 \mathrm{E}-07$ & $4.85 \mathrm{E}-07$ \\
\hline \multicolumn{11}{|c|}{10 um $5 \mathrm{~g} / \mathrm{cc}$} \\
\hline Distance (m) & 670 & 5200 & 8900 & 9200 & 9400 & 10000 & 10500 & 10900 & 11200 & 11500 \\
\hline $\mathrm{DV}(\mathrm{m} / \mathrm{s})$ & $2.15 \mathrm{E}-02$ & $2.29 \mathrm{E}-02$ & $2.29 \mathrm{E}-02$ & $2.35 \mathrm{E}-02$ & $2.35 \mathrm{E}-02$ & $2.36 \mathrm{E}-02$ & $2.36 \mathrm{E}-02$ & $2.36 \mathrm{E}-02$ & $2.37 \mathrm{E}-02$ & $2.36 \mathrm{E}-02$ \\
\hline Stability & $\mathrm{F}$ & $E$ & E & D & D & D & D & D & D & D \\
\hline Speed $(\mathrm{m} / \mathrm{s})$ & 3.8 & 4.6 & 4.6 & 4.9 & 5.0 & 5.2 & 5.4 & 5.2 & 5.7 & 5.3 \\
\hline$\chi / Q\left(s / m^{3}\right)$ & $1.89 \mathrm{E}-04$ & $87 \mathrm{E}-06$ & $14 \mathrm{E}-07$ & $75 E-07$ & $.54 \mathrm{E}-07$ & $96 \mathrm{E}-07$ & $55 E-07$ & $26 \mathrm{E}-07$ & $.06 \mathrm{E}-07$ & $3.88 \mathrm{E}-07$ \\
\hline
\end{tabular}


Figure 11. Dry deposition velocity $(\mathrm{DV}, \mathrm{m} / \mathrm{s})$ for $95^{\text {th }}$ percentile Savannah River Site conditions as a function of downwind distance for multiple combinations of particle size and density. (Figure 11b: same plot including 3 outlier points.)

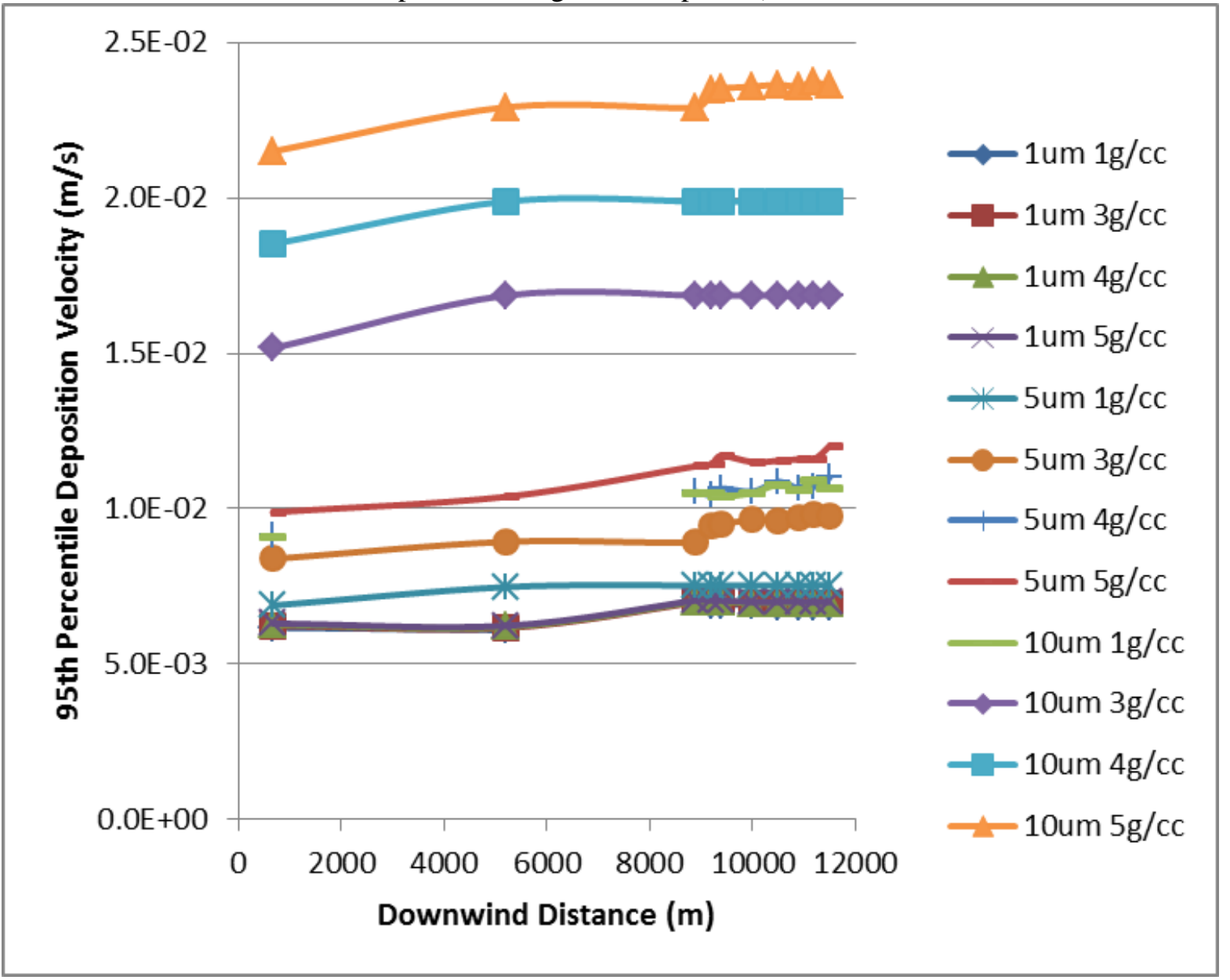

Figure 11b. Figure 11 reproduced with 3 outlier points added.

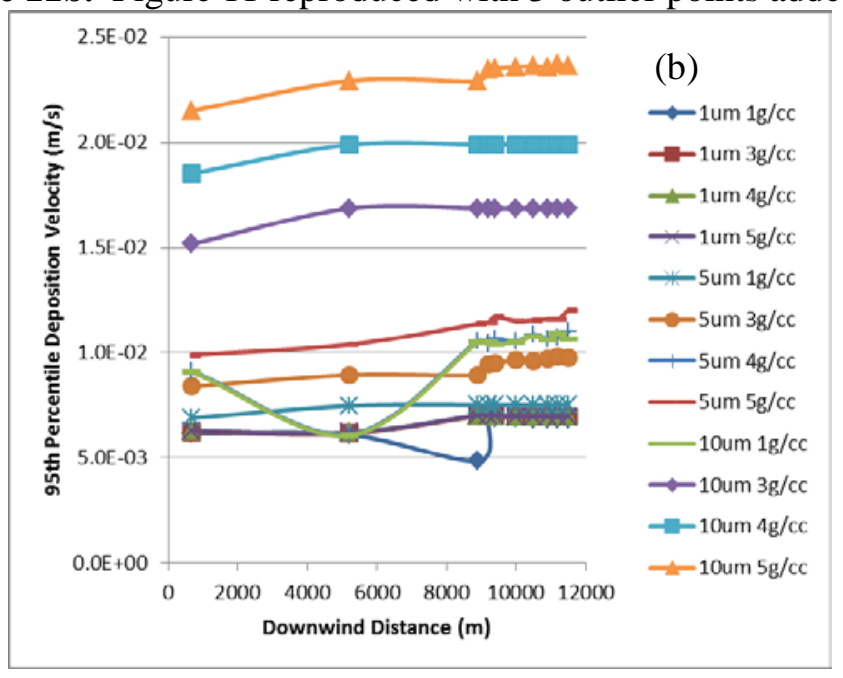


Table 4. Conversion of 61-meter wind speeds to 10-meter height with use of GENII (Napier et al. 2013) and Hunter and Viner (2013) algorithms

\begin{tabular}{|c|c|c|c|}
\hline Stability Class & $\begin{array}{c}\text { 61-m speed } \\
(\mathrm{m} / \mathrm{s})\end{array}$ & $\begin{array}{c}\text { GENII } \\
\text { 10-m Speed } \\
(\mathrm{m} / \mathrm{s})\end{array}$ & $\begin{array}{l}\text { Hunter and } \\
\text { Viner } 10-\mathrm{m} \\
\text { Speed }(\mathrm{m} / \mathrm{s})\end{array}$ \\
\hline$F$ & 2.10 & 0.75 & 0.78 \\
\hline $\mathrm{F}$ & 3.00 & 1.07 & 1.11 \\
\hline $\mathrm{F}$ & 3.10 & 1.11 & 1.15 \\
\hline$F$ & 3.30 & 1.18 & 1.22 \\
\hline$F$ & 3.80 & 1.36 & 1.41 \\
\hline $\mathrm{F}$ & 3.90 & 1.39 & 1.44 \\
\hline$F$ & 4.00 & 1.43 & 1.48 \\
\hline$F$ & 4.10 & 1.47 & 1.52 \\
\hline$F$ & 4.20 & 1.50 & 1.55 \\
\hline $\mathrm{F}$ & 4.30 & 1.54 & 1.59 \\
\hline$E$ & 3.30 & 1.44 & 1.75 \\
\hline$E$ & 3.40 & 1.48 & 1.81 \\
\hline$E$ & 3.60 & 1.57 & 1.91 \\
\hline$E$ & 3.70 & 1.61 & 1.96 \\
\hline$E$ & 3.90 & 1.70 & 2.07 \\
\hline$E$ & 4.00 & 1.74 & 2.12 \\
\hline $\mathrm{E}$ & 4.10 & 1.78 & 2.18 \\
\hline $\mathrm{E}$ & 4.20 & 1.83 & 2.23 \\
\hline$E$ & 4.30 & 1.87 & 2.28 \\
\hline$E$ & 4.40 & 1.91 & 2.34 \\
\hline $\mathrm{E}$ & 4.50 & 1.96 & 2.39 \\
\hline $\mathrm{E}$ & 4.60 & 2.00 & 2.44 \\
\hline$E$ & 4.80 & 2.09 & 2.55 \\
\hline$E$ & 4.80 & 2.09 & 2.55 \\
\hline$E$ & 5.00 & 2.18 & 2.66 \\
\hline$E$ & 5.80 & 2.52 & 3.08 \\
\hline $\mathrm{D}$ & 4.90 & 2.47 & 3.74 \\
\hline $\mathrm{D}$ & 5.00 & 2.52 & 3.81 \\
\hline $\mathrm{D}$ & 5.20 & 2.62 & 3.96 \\
\hline $\mathrm{D}$ & 5.40 & 2.72 & 4.12 \\
\hline $\mathrm{D}$ & 5.70 & 2.87 & 4.35 \\
\hline $\mathrm{D}$ & 5.80 & 2.92 & 4.42 \\
\hline
\end{tabular}

Note that in Table 3 and Figure 11, there are three "outlier" points that do not quite fit the pattern of the other 121 points. For these points, the random nature of the meteorological data has resulted in combinations of conditions that do not quite fit the general pattern. These three points have been omitted 
from Figure 11, but are included in Figure 11b. Two of these "outliers” are actually associated with the same weather pattern; all are within about $20 \%$ to $30 \%$ of the others and are neglected in the subsequent recommendations. The authors believe these three points to result from statistical variation and not from a significant divergence from the general conclusions. 


\section{Discussion and Recommendations}

This report is the second for the evaluation of dry deposition velocity (DV) for the Savannah River Site. In this report, a parametric analysis has been performed on DV by varying assumptions about surface roughness parameters and particle size and density. Meteorological conditions evaluated include atmospheric stability classes D, E, and F and wind speeds of $0.5,1.0,1.5$, and $3.0 \mathrm{~m} / \mathrm{s}$. Local surface roughness values ranging from 0.03 to 2 meters were evaluated. Particles with mass mean diameters of 1 , 5 , and 10 microns and densities of $1,3,4$, and $5 \mathrm{~g} / \mathrm{cm}^{3}$ were evaluated. Also in this analysis, the DV was investigated using actual SRS meteorological data and the DV anticipated to accompany $95^{\text {th }}$ percentile dispersion conditions was evaluated.

Each of the parameters that were varied has an influence on the DV. Some parameters have a larger influence than others on DV for various combinations of conditions. Mass mean particle size and density (or, combined, the mean particle mass) have the greatest effect, because large particles are highly influenced by gravitational settling. Wind speed and stability class also have a relatively large influence; it is anticipated that the $95^{\text {th }}$ percentile conditions at SRS will be a highly stable, low wind combination, somewhat akin to the $1.0 \mathrm{~m} / \mathrm{s}$ and Class F combination included in this evaluation. These combinations, as illustrated in Figures $1-8$, tend to have the lowest values of DV. The influence of local surface roughness has a relatively minor impact for large particles - generally less than a factor of two over the range of surface roughness from 0.03 to $2 \mathrm{~m}$. For small, light particles, the surface roughness can impact the DV by factors of 2 to 4 for Class D and up to a factor of 5 for Class F.

It must be kept in mind that DV is only one factor in the final estimation of the concentration of materials in the atmosphere after a release; besides influencing DV itself, wind speed and stability are the major determining factors in downwind concentration.

It is apparent from Table 3 and Figure 11 that the DV varies slightly with downwind distance. This is a result of plume depletion; as the plume moves farther away from the source, some of the material is left on the intervening ground surface. However, less material is deposited at higher wind speeds, because at higher speeds the travel time is reduced and there is less time for material to fall out of the plume.

Because higher wind speeds are generally correlated with neutral (D) and near neutral (C,E) stability classes, there is a transition point at or beyond around 5200 meters where, for the larger, denser particles, the most stable conditions (with low wind speeds) actually have a lower air concentration than less stable, but more transporting, higher wind speeds. This transition is more pronounced for the very large, dense particles, and for 10 micrometer diameter particles with density of $5 \mathrm{~g} / \mathrm{cm}^{3}$ or more, Pasquill stability class $\mathrm{D}$ actually results in the highest respirable air concentrations. This is a non-intuitive result that varies from the usual assumption that slow, stable conditions (exemplified by $1 \mathrm{~m} / \mathrm{s}$, Class F) are always the worst.

There are three possible ways that the information provided in this report could be used with the MACCS2 code (Chanin and Young 1998; DOE 2004): 
- The simplest and most conservative would be to take the smallest value of DV found for any combination of meteorological data at the $95^{\text {th }}$ percentile, about $0.0062 \mathrm{~m} / \mathrm{s}$ (Table 4), which is valid for 1 micron particles of essentially any density.

- At the other extreme, it would be possible to use the value reported in Table 3 for the conservative average size and density of particle, along with the associated wind speed and stability class. This would be the "most accurate" method of approximating the GENII output with the MACCS code, but would entail use of a different DV for nearly all particle size, density, and distance permutation. Because the GENII models are also only approximations to the complex physics involved, this level of detail seems unnecessary.

- An intermediate approach that would be adequate would be to use a representative set of DV and weather values from Table 3 for distances less than about 8000 meters, and a larger DV value and corresponding weather for longer distances. For example, for 1 micron diameter particles of essentially any density

o At distances of $<8000 \mathrm{~m}$, use $\mathrm{DV}=0.0061 \mathrm{~m} / \mathrm{s}$ and a corresponding wind speed of 3 $\mathrm{m} / \mathrm{s}$ at 61 meter height (equivalent to $1.1 \mathrm{~m} / \mathrm{s}$ at 10 meters) and stability class F;

o At distances of $>8000 \mathrm{~m}$, use DV $=0.0071 \mathrm{~m} / \mathrm{s}$ and a corresponding wind speed of $4.1 \mathrm{~m} / \mathrm{s}$ at 61 meter height (equivalent to $1.5 \mathrm{~m} / \mathrm{s}$ at 10 meters) and stability class F.

The authors believe that the third alternative, applied for the particle size/density combination of interest in SRS safety assessments, would be an adequate and defensible approach. 


\section{NQA-1 Software Quality Assurance at PNNL}

The GENII Software Quality Assurance (SQA) Manual (PNNL 2013), created in accordance with the PNNL QAPD, contains the SQA requirements for the development, procurement, maintenance, and use of software, for the software activities involved with GENII. The SQA requirements contained in the manual are designed to fulfill the requirements of ASME NQA-1a-2009, Subpart 2.7 (as shown in Attachment 1 of the manual). GENII is in compliance with meeting the SQA requirements in NQA-1a2009 Addenda, Part II, Subpart 2.7 Quality Assurance Requirements for Computer Software for Nuclear Facility Applications and DOE Order (O) 414.1D, Quality Assurance, and DOE Guide 414.1-4, Safety Software Guide for Use with 10 CFR 830, Subpart A, Quality Assurance Requirements. GENII is also in compliance with NQA-1 Part 1 Requirements for Quality Assurance Programs for Nuclear Facilities (as shown in Attachment 2 of the manual).

GENII software adheres to the quality program as evidenced by the following:

- The DOE Office of Quality Assurance, within the Office of Health, Safety, and Security, completed an evaluation of GENII Version 2.10 for inclusion in the DOE safety software Central Registry (the DOE “toolbox”) (DOE 2012). The DOE evaluation identified 5 recommendations to complete meeting of the DOE quality assurance requirements and criteria in DOE Order (O) 414.1C, Quality Assurance, and DOE Guide 414.1-4, Safety Software Guide for Use with 10 CFR 830, Subpart A, Quality Assurance Requirements. Those five recommendations have been addressed and GENII Version 2.10.1 will soon be available to all users through the DOE toolbox.

- $\quad$ PNNL conducted an internal software assessment on the GENII software in February 2013. This assessment was conducted utilizing the GENII SQA Manual, DOE Order (O) 414.1D, Quality Assurance, and DOE Guide 414.1-4, Safety Software Guide for Use with 10 CFR 830, Subpart A, Quality Assurance Requirements. The assessment identified 2 recommendations that were resolved. 


\section{References}

Aoyama M, K Hirose, Y Suzuki, H Inoue, and Y Sugimura. 1986. "High level radioactive nuclides in Japan in May.” Nature 321:819-820.

Bondietti EA, Brantley JN. 1986. “Characteristics of Chernobyl radioactivity in Tennessee.” Nature 322:313-314.

Bowen BM. 1996. Neutral Surface Layer Turbulence Over Complex Terrain, UCRL-JC-121086, Lawrence Livermore National Laboratory, Livermore, California.

Businger JA, JC Wyngaard, Y Izumi, EF Bradley. 1971. "Flux-Profile Relationships in the Atmospheric Surface Layer.” Journal of the Atmospheric Sciences 28(2):181-189.

Cambray RS, Cawse PA, Garland JA, Gibson AB, Johnson P, Lewis GNJ, Newton D, Salmon L, Wade BO. 1987. "Observations on radioactivity from the Chernobyl accident.” Nuclear Energy 26:77-101.

Chanin DI, ML Young. 1998. Code Manual for MACCS2: Volume 1, User's Guide. Sandia National Laboratories. SAND97-0594.

DOE - U.S. Department of Energy. 2004. "MACCS2 Computer Code Application Guidance for Documented Safety Analysis Final Report.” DOE-EH-4.2.1.1-MACCS2-Code Guidance.

DOE - U.S. Department of Energy. 2011. "Identification of Non-Conservative Accident Analysis Parameters,” HSS Safety Bulletin No. 2011-02.

DOE - U.S. Department of Energy. 2012. "Software Evaluation of GENII V2.10 with FRAMES v1.7 for Inclusion in the DOE Safety Software Central Registry,” HSS-CR-2011-1.

EPA - U.S. Environmental Protection Agency. 1995. "User’s Guide for the Industrial Source Complex (ISC3) Dispersion Models Volume II - Description of Model Algorithms.” EPA-454/B-95-003b. Research Triangle Park, North Carolina.

Elliott S. 2013. “SRS-Specific Particle Deposition Velocity Calculaton Part 2,” S-ESR-G-00024 Rev. 0, Savannah River Nuclear Solutions, Aiken, South Carolina.

Golder D. 1972. "Relations Among Stability Parameters in the Surface Layer.” Boundary-Layer Meteorology 3(1):47-58.

Horst TW. 1977. A surface depletion model for deposition from a Gaussian plume. Atmospheric Environment. Vol 11, Issue 1: 41-46.

Hunter CH, BJ Viner. 2013. Revised Meteorological Data Sets for Safety Related Atmospheric Dispersion Modeling (U), SRNL-STI-2012-00648, Revision 1, Savannah River National Laboratory, Aiken, South Carolina. 
Ludwick JD. 1964. "Investigation of the nature of I-131 in the atmosphere.” In Hanford Radiological Sciences Research and Development Annual Report for 1963, eds CC Gamertsfelder and JK Green, HW-81746, General Electric Co., Hanford Atomic Products Operation, Richland, Washington.

Ludwick JD. “A portable boom-type air sampler.” In Pacific Northwest Laboratory Annual Report for 1966 to the USAEC Division of Biology and Medicine. Vol. II: Physical Sciences, Part 1, Atmospheric sciences, eds DW Pearce and MR Compton. BNWL-481 1; 1967: 87-92, Pacific Northwest Laboratory, Richland, Washington.

Monin AS and AM Obukhov. 1954. "Basic Laws of Turbulent Mixing in the Ground Layer of the Atmosphere.” Trans. Geophys, Inst. Akad. Nauk, USSR 151:163-187.

Mueck K. 1988. "Variations in activity concentration and radionuclide ratio in air after the Chernobyl accident and its relevance to inhalation dose estimates.” Radiation Protection Dosimetry 22:219- 229.

Napier BA, DL Strenge, JV Ramsdell, Jr, PW Eslinger, and CJ Fosmire. 2012. GENII Version 2 Software Design Document. PNNL-14584, Rev. 4, Pacific Northwest National Laboratory, Richland, WA.

Napier BA. 2012. Dry Deposition Velocity Estimation for the Savannah River Site: Part 1 - Parametric Analysis, PNNL-21144, Pacific Northwest National Laboratory

Pacific Northwest National Laboratory (PNNL). 2013. GENII Software Quality Assurance Manual, Revision 3, Pacific Northwest National Laboratory, Richland, WA.

Pacific Northwest National Laboratory (PNNL). 2012. Quality Assurance Program Description, Pacific Northwest National Laboratory, Richland, WA.

Panofsky HA, Dutton JA. 1984. Atmospheric Turbulence. J. Wiley \& Sons, New York.

Paulson CA. 1970. "The Mathematical Representation of Wind Speed and Temperature Profiles in the Unstable Atmospheric Surface Layer.” Journal of Applied Meteorology 9(6):857-861.

Perkins RW. 1963. "Studies of radioiodine and other fallout radionuclides in air.” In Hanford Radiological Sciences Research and Development Annual Report for 1962, eds CC Gamertsfelder, JK Green. HW-77609:3.36 -3.48, General Electric Co., Hanford Atomic Products Operation; Richland, Washington.

Perkins RW. 1964. "Physical and chemical forms of I-131 from fallout and chemical processing plants." In Hanford Radiological Sciences Research and Development Annual Report for 1963, eds CC Gamertsfelder, JK Green. HW-81746:3.55-3.58, General Electric Co., Hanford Atomic Products Operation; Richland, Washington.

Ramsdell JV Jr., CA Simonen, and KW Burk. 1994. "Regional Atmospheric Transport Code for Hanford Emission Tracking (RATCHET).” PNWD-2224 HEDR, Pacific Northwest National Laboratory, Richland, Washington. 
Sehmel GA. 1984. “Deposition and Resuspension,” In Atmospheric Science and Power Production, ed Randerson D. DOE/TIC-27601, US Department of Energy, Springfield, Virginia.

Seinfeld JH. 1986. Atmospheric Chemistry and Physics of Air Pollution. John Wiley \& Sons, New York.

Van der Hoven I. 1968. "Deposition of particles and gases.” Meteorology and Atomic Energy. D. Slade (ed.), U.S. Atomic Energy Commission, pp. 202-208 TID-24190.

Voilleque PG. 1979. Iodine species in reactor effluents and in the environment. EPRI-NP-1269, Palo Alto, CA: Electric Power Research Institute.

Weber AH, RJ Kurzeja, CH Hunter. 2012. Roughness Lengths for the Savannah River Site. SRNL-STI2012-00016 Revision 1, Savannah River National Laboratory, Aiken, South Carolina. 


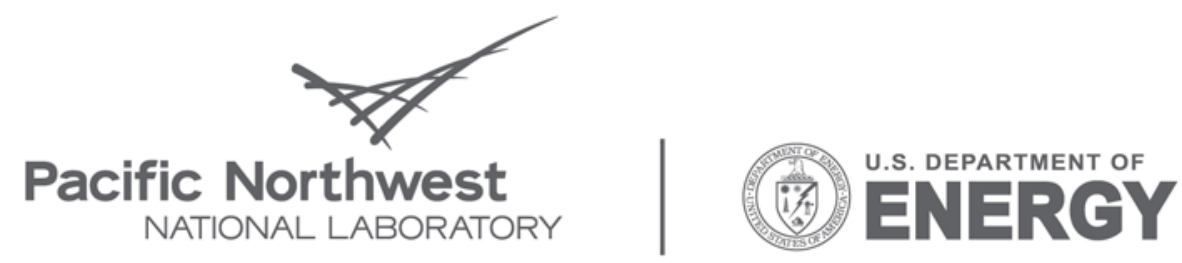

Proudly Operated by Battelle Since 1965

902 Battelle Boulevard

P.O. Box 999

Richland, WA 99352

1-888-375-PNNL (7665)

www.pnl.gov 